\title{
Nutrition and the HIV-associated lipodystrophy syndrome
}

\author{
Cathríona Rosemary Loonam and Anne Mullen* \\ Diabetes and Nutritional Sciences Division, School of Medicine, King's College London, Franklin-Wilkins Building, \\ 150 Stamford Street, London SE1 9NH, UK
}

(Submitted 25 March 2011 - Final revision received 19 June 2012 - Accepted 12 July 2012)

\section{Abstract}

HIV-associated lipodystrophy syndrome (HALS), comprising metabolic and morphological alterations, is a known side effect of highly active antiretroviral therapy (HAART). Evidence for the role of nutrition in the management of the systemic parameters of HALS is currently limited. In the present paper we review the current knowledge base surrounding HALS, focusing particularly on the role of nutrition in mitigating the systemic parameters of the syndrome. Reported prevalence of HALS was found to vary from 9 to $83 \%$ due to lack of a standardised definition, as well as variations in assessment methods and in the study population used. HALS is associated with both morphological (lipoatrophy, lipohypertrophy) and metabolic (dyslipidaemia, glucose intolerance, diabetes, hypertension, endothelial dysfunction and atherosclerosis) alterations, which may occur singly or in combination, and are associated with an increased risk of CVD. HAART-induced adipocyte inflammation, oxidative stress and macrophage infiltration, as well as altered adipocyte function and mitochondrial toxicity, have been shown to be central to the development of HALS. The adipocyte, therefore, represents a plausible target for treatment. Pharmacological and surgical treatment interventions have shown effect. However, their use is associated with numerous adverse effects and complications. Targeted lifestyle interventions may provide a useful alternative for managing HALS owing to their safety and tolerability. A Mediterranean-style diet has been found to be effective in improving the systemic parameters of HALS. Furthermore, the effects of $n-3$ PUFA supplementation are encouraging and future randomised controlled trials investigating the beneficial effects of $n-3$ PUFA in HALS are justified.

Key words: HIV-associated lipodystrophy syndrome: Highly active antiretroviral therapy: Nutrition therapy: Mediterranean diet: $n$-3 PUFA

\section{Introduction}

The number of individuals living with HIV/AIDS has increased globally ${ }^{(1)}$, with a current estimated global prevalence of 33.3 million $^{(2)}$. In the UK alone, the incidence of HIV/AIDS has almost doubled in the past decade and there are now an estimated 86200 individuals living with HIV/AIDS $^{(3)}$. This represents less than $1 \%$ of the global HIV/AIDS population, while Sub-Saharan Africa remains most severely affected by the HIV pandemic, with $67 \%$ of the global HIV/AIDS population located here ${ }^{(2)}$.

A significant turning point in the management of HIV came with the introduction of the nucleoside RT inhibitor (NRTI) zidovudine (ZDV), the first antiretroviral drug approved by the Food and Drug Administration in $1987^{(4)}$. For those with access to antiretroviral therapy (ART), HIV infection no longer represented an immediate threat to mortality ${ }^{(5)}$, and was, in many cases, transformed into a chronic condition.

The development of subsequent antiretroviral drugs zalcitabine (ddC), didanosine (ddI) and stavudine (d4T) led to combination ART (CART), the first of which was ZDV and $\mathrm{ddC}^{(6)}$. cART, commonly referred to as highly active ART, consists of at least two antiretrovirals, most usually from one of three main drug classes: NRTI and nucleotide RT inhibitors (NtRTI), protease inhibitors (PI) and non-nucleoside RT inhibitors $\left(\right.$ NNRTI) ${ }^{(7)}$. NRTI and NtRTI interact with the substrate-binding site of the HIV RT enzyme ${ }^{(8)}$, which halts the production of new virions ${ }^{(9,10)}$. NNRTI bind specifically with a non-substrate-binding site of RT, disrupting the enzyme's catalytic site ${ }^{(8,11)}$; PI inhibit the protease enzyme, thus preventing the host cell from cleaving the viral proteins into active viral particles ${ }^{(11)}$; fusion inhibitors

\footnotetext{
Abbreviations: ART, antiretroviral therapy; cART, combination antiretroviral therapy; CT, computed tomography; d4T, stavudine; HALS, HIV-associated lipodystrophy syndrome; LA, lipoatrophy; LH, lipohypertrophy; MI, myocardial infarction; $n$-3 LC-PUFA, n-3 long-chain PUFA; NCEP ATP III, National Cholesterol Education Program Adult Treatment Panel III; NNRTI, non-nucleoside RT inhibitor; NRTI, nucleoside RT inhibitor; PI, protease inhibitor; REE, resting energy expenditure; T2DM, type 2 diabetes mellitus; ZDV, zidovudine.
}

*Corresponding author: Dr Anne Mullen, fax +44207848 4171, email anne.mullen@kcl.ac.uk 
prevent viral capsid entry into the host cell by blocking the attachment, co-receptor binding and fusion of the viral particle ${ }^{(12)}$; C-C chemokine receptor type-5 (CCR5) inhibitors prevent viral entry into the host cell by inhibiting CCR5 signalling, which allows the virus to enter its target cell $^{(13)}$; integrase inhibitors, a new class of antiretrovirals, inhibit the insertion of the HIV pro-viral DNA into the host cell genome ${ }^{(14)}$.

Shortly after the introduction of PI, which were in the context of sole use or cART, case reports of disorders of glucose metabolism ${ }^{(15)}$ and alterations in body fat distribution $^{(16-19)}$ began to appear in the literature. HIVassociated lipodystrophy syndrome (HALS) was the term subsequently used to define these metabolic and morphological alterations, and was first described in 1998 by Carr et $a{ }^{(20)}$. Though ART, particularly PI and NRTI, are the main drivers of HALS, the virus itself and host genetics also contribute to its pathogenesis ${ }^{(21)}$.

HALS comprises peripheral lipoatrophy (LA) and central lipohypertrophy $(\mathrm{LH})^{(22)}$, which can occur together or sep$\operatorname{arately}^{(23)}$, dyslipidaemia ${ }^{(24)}$, insulin resistance ${ }^{(25)}$, type 2 diabetes mellitus $(\mathrm{T} 2 \mathrm{DM})^{(26-28)}$, hypertension ${ }^{(25)}$, endothelial dysfunction ${ }^{(29)}$, and altered cytokine and adipokine production $^{(29)}$. Collectively these abnormalities have been associated with an increased risk of CVD in this population ${ }^{(30-32)}$. HALS has been associated with risk factors for premature CVD and premature myocardial infarction (MI) ${ }^{(33-38)}$.

Nutrition plays a key role in maintaining health in HIV infected individuals ${ }^{(39)}$. According to a recent consensus statement from the American Dietetic Association( ${ }^{39)}$, evidence on the role of diet in mitigating systemic parameters in HALS is limited. There are a number of studies that have generally investigated the area by cross-sectional analysis of diet and systemic parameters of HIV-positive adults with and without HALS. Existing evidence indicates the potential benefit of a diet high in fibre ${ }^{(40,41)}$ and $\mathrm{Ca}^{(42)}$, which includes polyunsaturated fat ${ }^{(43)}$, and which corresponds with a Mediterranean-style dietary pattern ${ }^{(44,45)}$ in lowering the risk of metabolic and morphological abnormalities in HALS.

In the present article, we aim to review the existing knowledge base surrounding HALS, including epidemiology, associated metabolic and morphologic complications, potential molecular mechanisms involved in its pathogenesis, as well as strategies used in the management of the condition, focusing particularly on the potential role of nutrition in mitigating the complications of the syndrome.

\section{Prevalence and definition}

The prevalence of HALS has been shown to vary widely from 9 to $83 \%$ depending on the assessment criteria used (Table 1). Furthermore, the study populations used to assess prevalence of the condition may also account for the observed differences in published prevalence.
The majority of studies recruit only HIV-infected individuals receiving ART or those receiving ART and ART-naive comparisons. Five studies compare those with HIV infection with those without HIV infection ${ }^{(20,32,46-48)}$, and only one of these compares prevalence rates between HIV-infected individuals receiving PI, those who were PInaive and healthy men ${ }^{(20)}$.

The methods used to identify HALS also greatly affect prevalence estimates. Currently used methods include patient self-report, physician examination/report, a combination of these, anthropometric indices, biochemical indices, dual-energy X-ray absorptiometry, computed tomography (CT) and MRI. Patient self-report and physician report are commonly used methods; however, the accuracy of these subjective methods has not been evaluated ${ }^{(49)}$, and physician and patient assessments of HALS have been shown to vary ${ }^{(50)}$.

Carter et $a l .{ }^{(51)}$ showed that differences in the definition of the syndrome can contribute to a variation in prevalence of between 19 and $65 \%$. Existing definitions include LA or $\mathrm{LH}^{(48,52-62)}$, LA alone ${ }^{(20,61-75)}$, LH alone ${ }^{(61-68,70-78)}$, or a combination of LA and $\mathrm{LH}^{(52,54,55,61,62,64,66-68,71-75,79-85)}$. The main definitions for the metabolic alterations associated with HALS (abdominal obesity, dyslipidaemia, raised blood pressure, insulin resistance and a proinflammatory, prothrombotic state) are the National Cholesterol Education Program Adult Treatment Panel (NCEP ATP) III criteria ${ }^{(86)}$, used by the majority of researchers $^{(24,25,32,47,73,87,88)}$, the International Diabetes Federation (IDF) Guidelines ${ }^{(89)}$ used in one study ${ }^{(75)}$, a combination of NCEP and IDF used in three studies ${ }^{(25,88,90)}$, the 'Report of the National Heart, Lung, and Blood Institute/ American Heart Association Conference on Scientific Issues Related to Definition,(91) ${ }^{\text {used in one study }}{ }^{(46)}$, and the US National Institutes of Health Division of AIDS definition (2004 version) $)^{(92)}$ used in one study ${ }^{(93)}$. In addition to metabolic definitions, anthropometric techniques have been used in the identification of central adiposity in HALS ${ }^{(59)}$. The use of anthropometry in detecting small changes in fat distribution in HIV patients is, however, limited, as it is associated with inter-individual differences in the measurement of fat distribution in HIV patients ${ }^{(94)}$.

Carr et $a l^{(82)}$ have attempted to objectively define HALS and developed an objective case definition for the syndrome based on age, sex, duration of HIV infection, HIV disease stage, waist:hip ratio, anion gap, serum HDL concentration, trunk:peripheral fat ratio, percentage leg fat, and intra-abdominal:extra-abdominal fat ratio. This definition is $79 \%$ sensitive and $80 \%$ specific for the diagnosis and intensity of the syndrome. However, the definition requires anthropometric variables from dualenergy X-ray absorptiometry and CT, reducing its utility in clinical practice ${ }^{(50)}$.

Research has also focused on grading the severity of the components of HALS. The HIV Outpatient Study scale was 


\section{畺}

Table 1. Prevalence of the HIV-associated lipodystrophy syndrome (HALS)

\begin{tabular}{|c|c|c|c|c|c|}
\hline Authors & Study design & $n$ & Participants & Methods used to define HALS & Findings \\
\hline \multicolumn{6}{|l|}{ Western Europe } \\
\hline Bergersen et al. (2005) ${ }^{(103)}$ & CS & 308 & $\mathrm{HIV}+, \mathrm{F}$ & Anthro, Biochem & $37.3 \%$ of patients on ART v. $10.9 \%$ ART-naive \\
\hline Bernasconi et al. $(2002)^{(80)}$ & $\mathrm{P}$ & 1359 & HIV+, SHCS cohort & Self-report; physician report & $\begin{array}{l}43 \% \text { had at least one sign of HALS; } 28 \% \text { LA; } \\
30 \% \text { LH }\end{array}$ \\
\hline Boufassa et al. (2001) ${ }^{(52)}$ & CS & 685 & $\mathrm{HIV}+, 70.5 \% \mathrm{M}$ & Physician report & $58.8 \%$ HALS \\
\hline Chêne et al. (2002) & $\mathrm{RCT}^{*}$ & 120 & $\mathrm{HIV}+, 81 \% \mathrm{M}$ & Physician report; Biochem & $\begin{array}{l}31 \% \text { HALS after } 30 \text { months, } 18 \% \text { LA, } \\
6 \% \text { LH; } 7 \% \text { mixed }\end{array}$ \\
\hline Elgalib et al. $(2011)^{(88)}$ & CS & 678 & $\begin{array}{l}\text { HIV }+, 74 \% \mathrm{M}, \text { CREATE } \\
\text { cohort, } 74 \% \text { receiving ART }\end{array}$ & $\begin{array}{l}\text { IDF }(2005)^{(89)} \text { and NCEP } \\
\text { ATP III }{ }^{(86)} \text { criteria }\end{array}$ & $\begin{array}{l}25 \% \text { HALS (IDF, 2005); } 24 \% \text { HALS } \\
\text { (NCEP ATP III); } 68 \% \text { metabolic syndrome }\end{array}$ \\
\hline Fellay et al. (2001) ${ }^{(84)}$ & CS & 1160 & HIV+, SHCS cohort & $\begin{array}{l}\text { Physician report; according } \\
\text { to Carr et al. }(1998)^{(20)}\end{array}$ & $\begin{array}{l}47 \% \text { with clinical and } 27 \% \text { with laboratory } \\
\text { adverse events related to HALS }\end{array}$ \\
\hline Galli et al. (2002) ${ }^{(54)}$ & CS & 655 & HIV+, $72 \cdot 1 \%$ M, LipolCoNa study & $\begin{array}{l}\text { Self-report; retrospective and } \\
\text { prospective physician reports }\end{array}$ & $19.5 \%$ HALS \\
\hline Galli et al. (2003) ${ }^{(83)}$ & $\mathrm{P}$ & 212 & $\mathrm{HIV}+, \mathrm{F}$ & Self-report; physician report & $44.8 \%$ central LH; $42.9 \%$ peripheral LA; $33 \%$ mixed \\
\hline Galli et al. $(2003)^{(55)}$ & CS & 2258 & $\mathrm{HIV}+, 70 \% \mathrm{M}$ & Self-report; physician report & Adipose tissue alterations in $33.2 \%$ \\
\hline Gervasconi et al. (1999) ${ }^{(76)}$ & CS & 306 & $\mathrm{HIV}+, \mathrm{F}$ & Self-report; physician report; DXA & $10.4 \%$ HALS \\
\hline Goujard et al. (2001) & CS & 143 & HIV+, French PRIMO cohort & Physician report & $\begin{array}{l}\text { Cumulative incidence HALS } 5 \% \text {; increased } \\
\text { to } 9 \% \text { at } 12 \text { months and } 26 \% \text { at } 24 \text { months }\end{array}$ \\
\hline Jericó et al. $(2005)^{(87)}$ & CS & 710 & $\mathrm{HIV}+, 72 \% \mathrm{M}$ & $\begin{array}{l}\text { Physician report; Biochem; } \\
\text { NCEP ATP III }{ }^{(86)} \text { criteria }\end{array}$ & $17 \%$ metabolic syndrome \\
\hline Martínez et al. (2001) ${ }^{(79)}$ & $\mathrm{P}$ & 494 & $\mathrm{HIV}+, 76 \% \mathrm{M}$ & Self-report; physician report & $17 \%$ HALS \\
\hline Mauss et al. (2002) ${ }^{(64)}$ & csos & 221 & $\begin{array}{l}\text { HIV }+, 87 \% \text { M, DAGNAE } \\
\text { LipART cohort }\end{array}$ & Self-report; two physician reports & $34 \%$ HALS; $18 \%$ LA; $8 \%$ LH; $74 \%$ mixed \\
\hline Nguyen et al. $(2008)^{(60)}$ & $\mathrm{P}$ & 5427 & HIV,$+ 68 \% \mathrm{M}$, SHCS cohort & Physician report & $33.9 \%$ HALS \\
\hline Saint-Marc et al. $(2000)^{(63)}$ & CS & 154 & $\begin{array}{l}\text { HIV }+\mathrm{M} \text {, LIPOCO cohort, } \\
\text { ART experienced or ART-naive }\end{array}$ & Self-report; physician report & $\begin{array}{l}53.25 \% \text { HALS; } 15.89 \% \text { LA; } 4.21 \% \text { LH; } \\
18.22 \% \text { mixed }\end{array}$ \\
\hline Savès et al. (2002) ${ }^{(81)}$ & CS & 614 & HIV+, $80 \% \mathrm{M}$, APROCO cohort & Physician report & $62 \%$ HALS \\
\hline Seminari et al. $(2002)^{(61)}$ & $\mathrm{OB}$ & 504 & HIV,$+ M$, receiving ART & & $\begin{array}{l}39.3 \% \text { HALS; } 23 \% \text { LA; } 20 \% \text { LH; } 25 \% \text { mixed; } \\
32 \% \text { isolated metabolic alterations }\end{array}$ \\
\hline Thiébaut et al. $(2000)^{(64)}$ & CS & 581 & HIV,$+>13$ years, Aquitaine cohort & Physician report & $\begin{array}{l}38 \% \text { HALS; } 16 \% \text { LA; } 12 \% \text { LH; } 10 \% \text { mixed; } \\
54 \% \text { metabolic abnormalities }\end{array}$ \\
\hline Young et al. (2005) ${ }^{(58)}$ & $\mathrm{P}$ & 925 & HIV+, ART-naive & Self-report; physician report & $9 \%$ HALS \\
\hline $\begin{array}{l}\text { Eastern Europe } \\
\text { Jevtovic et al. }(2009)^{(73)}\end{array}$ & CS & 582 & $\mathrm{HIV}+$, stable on ART & Self-report; physician report & $\begin{array}{l}29.1 \% \text { HALS; } 47 \% \text { hyperlipidaemia; } \\
9.6 \% \text { T2DM }\end{array}$ \\
\hline \multicolumn{6}{|r|}{ - } \\
\hline $\begin{array}{l}\text { Rwanda } \\
\text { Mutimura et al. }(2007)^{(59)}\end{array}$ & $\mathrm{RT}$ & 571 & $\begin{array}{l}\text { HIV }+ \text {, receiving ART for } \\
\geq 6 \text { months }\end{array}$ & Self-report; confirmed by physician & $34 \%$ HALS; $9 \%$ LA; $19 \%$ LH; $72 \%$ mixed \\
\hline $\begin{array}{l}\text { van Griensven } \\
\text { et al. }(2007)^{(71)}\end{array}$ & CS & 409 & $\begin{array}{l}\text { HIV }+, 21.5 \% \mathrm{M} \text {, stable on } \\
\text { ART }>1 \text { year }\end{array}$ & Self-report; physician report & $\begin{array}{l}34.2 \% \text { HALS; } 9.8 \% \text { LA; } 4.9 \% \text { LH; } \\
\quad 19.6 \% \text { mixed }\end{array}$ \\
\hline \multicolumn{6}{|l|}{ Dakar } \\
\hline Mercier et al. (2009) ${ }^{(74)}$ & OB & 361 & $\begin{array}{l}181 \mathrm{HIV}+\text { cases and } \\
180 \mathrm{HIV}+ \\
\text { controls treated with } \\
\text { ART for } 4-9 \text { years }\end{array}$ & $\begin{array}{l}\text { Validated physician report of patients' } \\
\text { self-report using Carr et al. }(2003)^{(82)}\end{array}$ & $\begin{array}{l}31.1 \% \text { HALS; } 13.3 \% \text { LA; } 14.5 \% \text { LH; } \\
3.3 \% \text { mixed }\end{array}$ \\
\hline \multicolumn{6}{|l|}{ Benin } \\
\hline Zannou et al. (2009) $)^{(75)}$ & $\mathrm{P}$ & 79 & HIV,$+ 40.5 \% \mathrm{M}$, ART-naive & $\begin{array}{l}\text { Self-report; physician report; Biochem; } \\
\text { BIA; IDF (2005) }\end{array}$ & $\begin{array}{l}\text { Cumulative incidence HALS } 30 \% ; 9 \% \\
\text { LA; } 24 \% \text { LH; } 2.5 \% \text { mixed; } 13 \% \text { metabolic } \\
\text { syndrome }\end{array}$ \\
\hline \multicolumn{6}{|r|}{ 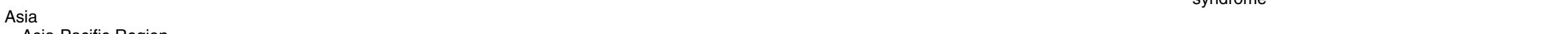 } \\
\hline \multirow[t]{2}{*}{$\begin{array}{l}\text { Asia-Pacific Region } \\
\text { Han et al. }(2011)^{(93)}\end{array}$} & OB & 2072 & HIV+ commencing ART & US NIH Division of AIDS & $10.5 \%$ HALS \\
\hline & & & & $\begin{array}{l}(2004 \text { version) })^{(92)} \\
\text { definition (severity grade } \geq 3 \text { ) }\end{array}$ & \\
\hline $\begin{array}{l}\text { West India } \\
\quad \text { Pujari et al. (2005) }{ }^{(70)}\end{array}$ & CS & 180 & $\begin{array}{l}\text { HIV }+ \text { cases and } 126 \mathrm{HIV}+ \\
\text { controls, receiving first-line } \\
\text { ART for }>1 \text { year }\end{array}$ & Self-report; physician report & $46.1 \%$ HALS \\
\hline
\end{tabular}


Table 1. Continued

\begin{tabular}{|c|c|c|c|c|c|}
\hline Authors & Study design & $n$ & Participants & Methods used to define HALS & Findings \\
\hline \multicolumn{6}{|l|}{ South India } \\
\hline $\begin{array}{l}\text { Kalyanasundaram } \\
\text { et al. (2012) }\end{array}$ & CS & 363 & $\begin{array}{l}145 \text { HIV+ on ART, } 146 \text { HIV+ } \\
\text { ART-naive, seventy-two HIV-; }\end{array}$ & - & $\begin{array}{l}60.7 \% \text { HALS; } 51.1 \% \text { LA; } 22.7 \% \text { LH; } \\
22.7 \% \text { mixed }\end{array}$ \\
\hline Singapore & & & & & \\
\hline Paton et al. $(2002)^{(68)}$ & CS & 410 & HIV+, receiving ART and ART-naive & Self-report & $45.9 \%$ LA; $32.4 \%$ LH; $8.3 \%$ mixed \\
\hline Thailand & & & & & \\
\hline $\begin{array}{l}\text { Puttawong } \\
\text { et al. (2004) }\end{array}$ & CS & 278 & $\mathrm{HIV}+, 60 \% \mathrm{M}, \mathrm{ART}$ and ART-naive & Self-report; physician report & $17 \%$ HALS \\
\hline \multicolumn{6}{|l|}{ Australia } \\
\hline Carr et al. $(1998)^{(20)}$ & CS & 295 & $\begin{array}{l}\text { HIV+, } 116 \text { receiving PI, thirty-two } \\
\text { PI-naive, forty-seven healthy men }\end{array}$ & Self-report; physician report & $64 \%$ HALS in PI recipients; $3 \%$ in PI-naive \\
\hline Carr et al. $(1999)^{(98)}$ & CS & 158 & HIV,+ 113 receiving PI, forty-five PI-naive & $\begin{array}{l}\text { Self-report; physician } \\
\text { report; DXA }\end{array}$ & $83 \%$ HALS in PI recipients; $4 \%$ in PI-naive \\
\hline Carr et al. $(2003)^{(82)}$ & $\mathrm{CC}$ & 1081 & HIV+, $85 \% \mathrm{M}, \mathrm{ART}$ and ART-naive & $\begin{array}{l}\text { Self-report; physician report; } \\
\text { Biochem; DXA: CT }\end{array}$ & $9 \%$ LA; $6 \%$ LH \\
\hline Carter et al. $(2001)^{(51)}$ & CS & 159 & $\begin{array}{l}\text { HIV }+\mathrm{M}, 76 \% \text { receiving } \mathrm{PI}, 14 \% \text { received } \\
\mathrm{PI} \text { in past, } 2.5 \% \text { ART-naive }\end{array}$ & $\begin{array}{l}\text { Self-report; physician report; } \\
\text { Biochem; Anthro; DXA }\end{array}$ & $\begin{array}{l}\text { HALS prevalence varied (19-65\%) } \\
\text { depending on the definition }\end{array}$ \\
\hline Miller et al. $(2003)^{(56)}$ & CS & 1348 & $\begin{array}{l}\text { HIV+, } 95 \% \mathrm{M},>17 \text { years, } 20 \% \text { AIDS, } \\
\text { ART and ART-naive comparisons }\end{array}$ & Physician assessment & $53 \%$ HALS; $20 \%$ LA; $6 \%$ LH; $27 \%$ mixed \\
\hline Samaras et al. (2007) ${ }^{(25)}$ & CS & 788 & $\begin{array}{l}\text { HIV+, Lipodystrophy Case Definition cohort, } \\
\text { ART and ART-naive }\end{array}$ & $\begin{array}{l}\text { Self-report; physician report; } \\
\text { Biochem; IDF }(2005)^{(89)} \\
\text { and NCEP ATP III }{ }^{(86)} \\
\text { criteria }\end{array}$ & $\begin{array}{l}\text { Metabolic syndrome: } 14 \% \text { (IDF, 2005); } \\
18 \% \text { (NCEP ATP III) }\end{array}$ \\
\hline \multicolumn{6}{|l|}{ USA and Canada } \\
\hline Heath et al. (2001) ${ }^{(78)}$ & $\mathrm{OB}$ & 1035 & $\begin{array}{l}\text { HIV }+, 92 \% \mathrm{M}, 62 \% \text { receiving } \mathrm{PI} \\
74 \% \mathrm{PI} \text {-naive }\end{array}$ & Self-report & $50 \%$ HALS; $36 \%$ LA; $33 \%$ LH \\
\hline Heath et al. $(2002)^{(66)}$ & $P$ & 366 & HIV+, $89 \% \mathrm{M}, \mathrm{ART}$-naive & Self-report; Biochem & $\begin{array}{l}\text { Cumulative incidence LA } 29 \% \text {; } 23 \% \text { LH; } \\
13 \% \text { mixed: } 9 \% \text { dyslipidaemia }\end{array}$ \\
\hline Jacobson et al. $(2006)^{(46)}$ & CS & 477 & $\begin{array}{l}\text { HIV+ cases, HIV - comparison group } \\
\text { from NHANES cohort, receiving ART }\end{array}$ & $\begin{array}{l}\text { Physician report; Biochem; } \\
\text { DXA; definition of } \\
\text { metabolic syndrome† }\end{array}$ & $24 \%$ metabolic syndrome \\
\hline Lichtenstein et al. (2001) ${ }^{(65)}$ & $\mathrm{OB}$ & 1077 & HIV,+ HOPS cohort, receiving ART & Self-report; physician report & $49 \%$ HALS \\
\hline Lichtenstein et al. $(2003)^{(69)}$ & $\mathrm{P}$ & 546 & HIV+, receiving ART & $\begin{array}{l}\text { Agreement between self-report } \\
\text { and physician report }\end{array}$ & $\begin{array}{l}13.1 \% \text { developed moderate/severe } \\
\text { LA after } 20 \text { months }\end{array}$ \\
\hline Mondy et al. $(2007)^{(32)}$ & PCS & 471 & $\mathrm{HIV}+, 66 \% \mathrm{M}$ & $\begin{array}{l}\text { Biochem; Anthro; NCEP } \\
\text { ATP III }{ }^{(86)} \text { criteria }\end{array}$ & $26 \%$ metabolic syndrome \\
\hline Sobieszczyk et al. $(2008)^{(47)}$ & CS & 2393 & $\begin{array}{l}\text { HIV+, F, } 1725 \text { seropositive, } \\
668 \text { high-risk seronegative }\end{array}$ & $\begin{array}{l}\text { Self-report; physician report; } \\
\text { Biochem; NCEP } \\
\text { ATP IIII }{ }^{(86)} \text { criteria }\end{array}$ & $33 \%$ metabolic syndrome \\
\hline Tien et al. $(2003)^{(48)}$ & $P$ & 605 & $\begin{array}{l}\text { HIV + cases, } 210 \text { HIV - controls, } \\
\text { Women's Interagency HIV cohort }\end{array}$ & Self-report; physician report & $48.6 \%$ HALS \\
\hline van der Valk et al. $(2001)^{(85)}$ & $\mathrm{RCT}$ & 175 & $\mathrm{HIV}+, \mathrm{Pl}$ - or stavudine-naive & Physician report & $17 \%$ HALS \\
\hline Walmsley et al. (2008) ${ }^{(72)}$ & $\mathrm{P}$ & 68 & $\mathrm{HIV}+, 85 \% \mathrm{M}$ & $\begin{array}{l}\text { Self-report; physician report; } \\
\text { Biochem; DXA, photographs } \\
\text { at baseline and every } 6 \text { months }\end{array}$ & $77 \%$ HALS; $25 \%$ LA; $32 \%$ LH; $19 \%$ mixed \\
\hline \multicolumn{6}{|l|}{$\begin{array}{l}\text { Multinational: EU, } \\
\text { Australia, USA }\end{array}$} \\
\hline Worm et al. (2010) & $\mathrm{POB}$ & 33347 & HIV+, DAD study cohort & $\begin{array}{l}\text { Biochem; modified NCEP } \\
\text { ATP III }{ }^{(86)} \text { criteria }\end{array}$ & $\begin{array}{l}\text { Metabolic syndrome increased from } \\
19.4 \text { to } 41.6 \% \text { between } 2000 \text { and } 2007\end{array}$ \\
\hline
\end{tabular}

CS, cross-sectional; HIV+, HIV-positive; F, female; Anthro, anthropometry; Biochem, biochemical assessment; ART, antiretroviral therapy; P, prospective study; SHCS, Swiss HIV Cohort Study; LA, lipoatrophy; LH, lipohypertrophy; M, male; RCT, randomised controlled trial; CREATE, Cardiovascular Risk Evaluation and Antiretroviral Therapy Effects; IDF, International Diabetes Federation; NCEP ATP III, National Cholesterol Education Program Adult Treatment Panel III; LipolCoNa, substudy of the Italian Cohort Naive Antiretrovirals; DXA, dual-energy X-ray absorptiometry; CSOS, cross-sectional observational study; APROCO, Antiproteases Cohorte; OB, observational study; NHANES, National Health and Nutrition Examination Survey; HOPS, HIV Out-Patient Study; PCS, prospective cross-sectional study; EU, European Union; POB, prospective observational study; DAD, Data Collection on Adverse Effects of Anti-HIV Drugs.

* Eong-term follow-up of a randomised controlled trial.

† Based on the 'Report of the National Heart, Lung, and Blood Institute/American Heart Association Conference on Scientific Issues Related to Definition'(91). 
one of the first methods used to assess the severity of HALS in different areas of the body, including the abdomen, arms, legs, hips/buttocks and face ${ }^{(65)}$. Abnormalities in each area were graded from 'subtle' (noticeable only if looked for; no change in clothing fit), to 'moderate' (easily noticed by patient or physician; clothing has become tight or loose) and 'severe' (obvious to the casual observer; has required a change in clothing size). All changes were graded both subjectively (patient selfreport) and objectively (physician examination) ${ }^{(65)}$. Subsequently, Carr \& Law ${ }^{(95)}$ developed a severity grading scale based on their objective case definition of HALS; however, in the same paper they recommended abandoning the assessment of lipodystrophy severity, and suggested the lipodystrophy case definition score provided the best objective measure of severity. Recently, Fontdevila et al. ${ }^{(96)}$ have developed a CT-validated grading system for determining the severity of facial LA based on the loss of facial bone and muscle structures. This grading system is recommended for use when comparing the efficacy of fat grafting procedures and, therefore, may not be ideal in routine clinical practice.

In the absence of a clear definition for HALS, the incidence and prevalence of the syndrome remain uncer$\operatorname{tain}^{(97)}$. It is clear that the definition and diagnostic criteria for HALS are poor, epidemiological data on its prevalence and incidence are also lacking, and as a result Guaraldi \& Baraboutis ${ }^{(97)}$ question whether HALS is over?'. In this paper, the authors suggest replacing the definition of HALS with the non-infectious co-morbidities that develop as a result of HIV infection.

\section{Morphological alterations}

In their original paper, Carr et al. ${ }^{(20)}$ refer to lipodystrophy as 'fat wasting of the face, limbs and upper trunk'. Further research by the same authors acknowledged lipid accumulation as another feature of HALS ${ }^{(98)}$. A review, published the same year, concluded that LA and LH are distinct entities with individual pathophysiological mechanisms underlying their development ${ }^{(99)}$. Although these early findings separate LA and LH in the definition of HALS, recent findings conclude that the abnormalities associated with HALS, including LA and LH, can occur singly or in combination $^{(22)}$; for the purposes of the present review they will be discussed separately.

\section{Lipoatrophy}

LA, characterised by loss of subcutaneous fat ${ }^{(100)}$, is distinctly different from the traditional HIV wasting syndrome, characterised by a disproportionate decrease in lean body mass $^{(101)}$. LA, as a side effect of ART, is seen mainly in the face (facial LA) and the extremities (peripheral LA) ${ }^{(63)}$. Fat wasting of the face usually presents as malar or temporal wasting ${ }^{(22)}$. Peripheral fat wasting typically occurs in the arms, shoulders, buttocks and legs ${ }^{(102)}$. The latter type of fat wasting is often accompanied by prominent superficial veins, which contribute to the emaciated appearance observed in these individuals ${ }^{(103)}$.

Initial reports attributed the development of $\mathrm{LA}$ to $\mathrm{PI}^{(20)}$; however, it is now known that the use of NRTI such as d4T is more strongly linked with its development ${ }^{(61,104)}$. Some NRTI combinations, such as $\mathrm{d} 4 \mathrm{~T}$ and didanosine (ddI), are contraindicated as a result of their severe lipoatrophic side effects ${ }^{(105)}$. In addition to type of ART, a number of other risk factors for LA have been identified including older age ${ }^{(105)}$, a decrease in BMI before $\mathrm{ART}^{(69)}$, white race $^{(69)}$, use of PI for greater than 2 years ${ }^{(98)}$, and factors relating to disease progression including lower CD4 cell count $^{(69)}$, duration and severity of HIV infection ${ }^{(65,106)}$ and prior diagnosis of $\operatorname{AIDS}^{(65)}$.

\section{Lipohypertrophy}

LH is characterised by adipose tissue accumulation mainly in the intra-abdominal ('Crix belly') (19,20,102,107,108) and dorsocervical ('buffalo hump') regions ${ }^{(17,18,109)}$. Other characteristic features of LH include breast enlargement, observed in both males and females ${ }^{(59,68,77,80,81)}$, accumulation of adipose tissue on the anterior region of the neck $^{(110)}$, side of the neck ${ }^{(59,68)}$, under the axillae ${ }^{(110)}$ and in the suprapubic region ${ }^{(111)}$, and localised or generalised lipomas ${ }^{(56)}$. LH is distinct from simple visceral fat accumulation, as it is associated with a decrease, rather than an increase, in subcutaneous fat ${ }^{(90,108)}$. It is worth noting that abdominal LH is the most commonly identified lipohypertrophic change in HALS patients ${ }^{(52,56,57,59,68,77-81,102)}$.

Risk factors associated with the development of LH in the context of HIV and ART include age, female sex, having a BMI of greater than $25 \mathrm{~kg} / \mathrm{m}^{2(260)}$, and having a low CD 4 cell count ${ }^{(65,69)}$. The type of ART has also been shown to play a role in the pathogenesis of LH. Jacobson et $a l^{(46)}$ demonstrated that LH was observed in both patients who have and have not been exposed to PI, indicating that PI are not the only cause of LH. Thymidine analogues in particular have been shown to increase the risk of developing $\mathrm{LH}^{(71)}$. Novel drugs, such as the peptidic HIV-1 fusion inhibitor enfuvirtide, have also recently been implicated in the development of $\mathrm{LH}^{(112)}$. In addition to the type of ART, a longer duration of treatment has been associated with an increased risk of developing $\mathrm{LH}^{(79)}$.

\section{Metabolic alterations}

\section{Dyslipidaemia}

Before the advent of ART, evidence suggested that HIV infection itself caused abnormalities of blood lipids ${ }^{(113,114)}$. One study investigating lipid abnormalities associated with seroconversion in men found that HIV infection was associated with a reduction in total 
cholesterol, LDL and $\mathrm{HDL}^{(115)}$. Subsequent initiation of ART in the same subjects led to a significant increase in total cholesterol and LDL concentrations from baseline to follow-up, confirming the role of ART in the pathogenesis of dyslipidaemia in $\mathrm{HIV}^{(115)}$.

The prevalence of lipid disorders in HIV-infected individuals treated with ART has been shown to vary from 24 to $72 \%{ }^{(53,64,70,75,88,116,117)}$. Characteristic lipid abnormalities associated with HALS include elevated total cholesterol and $\mathrm{LDL}$, elevated $\mathrm{TAG}^{(20)}$ and reduced $\mathrm{HDL}^{(118)}$. Early studies attributed the development of dyslipidaemia to PI therapy ${ }^{(119,120)}$. Subsequent studies have, however, shown that both NRTI and NNRTI are involved in the development of lipid abnormalities in $\mathrm{HIV}^{(121,122)}$. Furthermore, both in vitro and in vivo studies have demonstrated an association between cART and the development of more pronounced lipid abnormalities ${ }^{(118,123)}$. A recent UK study found that impaired postprandial TAG clearance in HIV patients receiving ART was exacerbated by a combination of NRTI and $\mathrm{PI}^{(124)}$. A recent retrospective cohort study from Brazil found that PI increased serum TAG but not total cholesterol concentrations in 102 HIV-infected patients ${ }^{(125)}$. In the same study NNRTI were associated with an increase in total cholesterol with no significant effect on TAG levels. Similarly, Walmsley et al. ${ }^{(72)}$ in their prospective cohort study of HIV patients found that after 12 months of treatment with NNRTI, only total cholesterol concentrations increased significantly. Results pertaining to the duration of ART and risk of lipodystrophy are inconsistent, with some showing that increased duration increases risk of dyslipidaemia ${ }^{(81,118)}$, while other studies have shown no effect of duration on the risk of dyslipidaemia $^{(32)}$

A number of factors have been identified which are associated with an increased risk of dyslipidaemia in patients receiving ART. Similar to the general population, dyslipidaemia in HIV has been shown to occur to a greater extent in female patients ${ }^{(126)}$. Although African-Americans in the general population have been shown to have a lower prevalence of hypertriacylglycerolaemia ${ }^{(127)}$, Foulkes et $a l .^{(128)}$ found that exposure to PI induced the greatest increase in TAG concentrations in black compared with white and Hispanic populations. This may indicate a role for race/ethnicity in increasing the risk of dyslipidaemia in HIV. It is important to note, however, that this study had, according to the authors, limited power, making it difficult to detect small interaction effects within these racial/ethnic groups. A number of polymorphisms of genes including $A P O A 5, A P O C 3, A P O E$, sterolregulatory element-binding protein-1c (SREBP1C) and $T N F$ have also been associated with an increased risk of dyslipidaemia in HIV-infected individuals ${ }^{(129-133)}$.

It has been suggested that the diagnosis of dyslipidaemia in HIV-infected individuals should be made using recommendations for non-HIV-infected individuals ${ }^{(90)}$. For the general population, dyslipidaemia is diagnosed using a fasting lipid profile and defined using the NCEP ATP III criteria. Ideally, fasting lipid profiles should be offered to patients before initiation of ART in order to gain an insight into the exact changes caused thereafter by ART ${ }^{(90)}$. LDL levels are the primary target of the NCEP ATP III guidelines, which recommend that lifestyle modifications be trialled first, followed by statins, to lower $\mathrm{LDL}^{(86)}$.

\section{Glucose abnormalities}

Before the ART era, the development of T2DM in HIVinfected individuals was attributed to the anti-microbial medication pentamidine ${ }^{(134)}$ and was relatively uncommon $^{(135)}$. Following the introduction of PI, however, a greater number of reported glucose disorders began to emerge in HIV-infected individuals ${ }^{(15,136,137)}$.

Abnormalities in fasting blood glucose concentration have been found in up to $20 \%$ of patients ${ }^{(64,72,74,88)}$, while prevalence figures for impaired fasting glucose $(59,74,75,81,88)$ and impaired glucose tolerance ${ }^{(57,72,73,81,98,116)}$ have been shown to vary from 3.8 to $18 \%$ and from 7 to $37 \%$, respectively. In comparison, the prevalence of impaired glucose tolerance and impaired fasting glucose in the general population is 8.4 and $6.3 \%$, respectively ${ }^{(138)}$.

Puttawong et $a l^{(57)}$ and Tomažič et al. ${ }^{(116)}$ identified the prevalence of insulin resistance in 30 and $38 \%$ of their HIV subjects, respectively. The prevalence of diabetes in the general population has been shown to be $9.8 \%$ for men and $9.2 \%$ for women ${ }^{(139)}$, while in patients receiving ART, prevalence has been shown to range from 7 to $27 \%(73,81,98,116)$. Although the aforementioned studies have shown a relationship between ART and glucose abnormalities in HALS, a number of studies have failed to show a relationship with either glycaemic parameters $^{(47,53,140)}$ or insulin resistance ${ }^{(141)}$, highlighting the inconsistencies that currently exist in the literature.

Risk factors for the development of glucose abnormalities in the context of HIV and ART have been recently reviewed and were found to include older age, existing LA, non-white race, family history of T2DM, and disease factors, such as co-infection with hepatitis $\mathrm{C}^{(90)}$. Furthermore, a recent study from Bangkok found that the risk of pre-diabetes in HIV-infected patients receiving ART increased with each $5 \mathrm{~kg}$ increase in body weight ${ }^{(142)}$. In the same study, the NNRTI nevirapine was found to be protective for pre-diabetes. Both in vitro and in vivo studies have demonstrated the negative effect of PI on glucose homeostasis in $\operatorname{HIV}^{(27,143,144)}$. Results from the Women's Interagency HIV Study showed that longer-term exposure to NRTI increased the incidence of T2DM, indicating their role in increasing the risk of glucose abnormalities in HALS ${ }^{(145)}$.

Diagnosis of glucose disorders in HALS is similar to the general population and has been made on the basis of guidelines from the International Diabetes Federation ${ }^{(89)}$ and the American Diabetes Association ${ }^{(146)}$. According to 
these guidelines, fasting plasma glucose greater than $5.6 \mathrm{mmol} / 1$ is defined as impaired glucose tolerance and a value greater than $7 \mathrm{mmol} / \mathrm{l}$ is indicative of frank diabetes. The American Diabetes Association criteria for diagnosing abnormalities of glucose metabolism state that patients must present with symptoms (polyuria, polydipsia, weight loss) and a random glucose of greater than $11.1 \mathrm{mmol} / \mathrm{l}$ for a diagnosis of diabetes to be made. Furthermore, Wohl et al. ${ }^{(147)}$ recommend follow-up with fasting blood glucose every 3-6 months for at-risk patients and those undergoing changes in their ART regimen.

\section{Hypertension}

Both LA and LH have been shown to be independently associated with hypertension in HIV-infected individuals receiving $\mathrm{ART}^{(148)}$. As for the general population, hypertension in HIV patients is associated with an increased risk of $\mathrm{CVD}^{(149)}$. A recent UK study of HIV patients with the metabolic syndrome found that raised systolic blood pressure was associated with risk factors such as being male, higher BMI and higher CD4 cell count and viral load ${ }^{(88,150)}$. Crane et al. ${ }^{(148)}$ suggest that increased BMI may be involved in mediating hypertension associated with LH in HALS. When the authors adjusted for BMI, patients with LA had an increased risk of hypertension compared with those without anthropometric abnormalities $^{(148)}$. The role of ART in mediating hypertension is somewhat unclear. A study by Thiébaut et al. ${ }^{(151)}$ showed that ART was not independently associated with any negative effects on blood pressure; in fact, use of NNRTI was associated with a lower risk of hypertension in this group.

\section{Carotid artery intima thickness}

Arterial stiffness has been shown to be an independent predictor of cardiovascular morbidity and mortality in the general population $^{(152)}$. Exposure to ART in HIV-infected individuals is associated with thickening of the carotid artery intima and arterial stiffness ${ }^{(153,154)}$. Recent findings from the Women's Interagency HIV Study and the Multicenter AIDS Cohort found a significant association between HIV-related immunosuppression and increased carotid artery stiffness, independent from the impact of ART or other traditional atherosclerotic risk factors ${ }^{(155)}$. These results suggest that disease factors may predict the development of arterial stiffness and subsequent atherosclerosis in HALS.

\section{Endothelial dysfunction}

Endothelial dysfunction is a critical initial step in the progression of atherosclerosis in HIV-infected individuals ${ }^{(156)}$. A recent prospective study showed that the presence of lipodystrophy predicted endothelial dysfunction in fifty-five HIV-infected patients, independent of other CVD risk factors ${ }^{(29)}$. Contrary to initial findings, different classes of ART have been implicated in the pathogenesis of endothelial dysfunction in HALS ${ }^{(29)}$. Currently, results appear conflicting, some showing that use of ART contributes to endothelial dysfunction ${ }^{(157)}$, some showing no association between ART and endothelial function ${ }^{(158)}$, and others showing improved endothelial function following treatment in previously ART-naive subjects ${ }^{(159)}$. Interestingly, recent in vitro work has shown increased oxidative stress and cellular senescence in human coronary artery endothelial cells following long-term exposure to ritonavir and lopinavir-ritonavir ${ }^{(160)}$, highlighting a potential mechanism for PI-associated endothelial dysfunction. Larger long-term prospective studies are, however, required to determine the effect of ART on endothelial dysfunction in vivo.

\section{Atherosclerosis}

Patients with lipodystrophy have been shown to be at a higher risk of atherosclerosis ${ }^{(161)}$. Calza et al. ${ }^{(162)}$ recently reviewed the link between HIV infection, ART and the development of premature atherosclerosis. Similar to the general population, the most commonly identified risk factors associated with atherosclerosis were age, smoking, increased BMI, hypertension and dyslipidaemia. Of nine studies, four found an association between the use of PI and premature atherosclerosis. Furthermore, three of five studies showed that HIV infection itself was associated with atherosclerosis. This, coupled with the association between risk of atherosclerosis and CD 4 cell count ${ }^{(163)}$, indicates that disease factors play an important role in the pathogenesis of atherosclerosis.

\section{CVD}

It has been well established that ART contributes to a 'metabolic syndrome' encompassing abdominal obesity, atherogenic dyslipidaemia, insulin resistance, endothelial dysfunction and inflammation, known as HALS. In recent years, therefore, research has begun to focus on the deleterious effects of ART on risk of CVD ${ }^{(135)}$

Early reports of CVD appeared in peer-reviewed literature shortly after the introduction of $\mathrm{PI}^{(164,165)}$. Evidence for the association between ART and increased risk of CVD is, at present, inconsistent. Some studies show no association between the use of ART and risk of CVD or cerebrovascular disease $^{(166)}$, while others show a positive association for $\mathrm{PI}^{(30,118,167,168)}$. Research has shown that between 5 and $31 \%$ of patients with HIV/AIDS are at risk for cardiovascular events ${ }^{(73,169,170)}$, and, similar to the general population, patients with the metabolic syndrome have a greater risk than those without ${ }^{(170)}$.

Variations in observed risk could be explained by differences in the risk factors of the study population. 
Commonly identified risk factors for MI or cardiovascular events include AIDS before ART initiation, age over 40 years, cigarette smoking ${ }^{(73)}$, family history of CVD, diagnosis of dyslipidaemia, hypertension, lipodystrophy or $\mathrm{T}_{2} \mathrm{DM}^{(167)}$ or pre-existing vascular disease ${ }^{(35)}$. Unlike the general population, Bozzette et al. ${ }^{(35)}$ showed that risk of serious cardiovascular events was lower for AfricanAmerican subjects, indicating that race/ethnicity may also be a risk factor. It has also been found that the prevalence of CVD is higher for patients receiving a combination of PI and $\mathrm{NNRTI}^{(118)}$. In a recent review, Schafer et al. ${ }^{(171)}$ referred to studies which show an increased risk of CVD associated with recent, but not cumulative, use of abacavir, a NRTI. However, a recent 96-week randomised controlled trial did not find an association between the NRTI combination abacavir-lamivudine and cardiovascular morbidity and mortality in HIV-infected individuals ${ }^{(172)}$. These researchers suggest that differences in results may be attributed to variations in pre-study viral load among patients. The increased longevity observed in the HIV population as a result of advanced drug therapy has also been associated with an increase in the incidence of $\mathrm{CVD}^{(173)}$. Evidence indicates that disease progression and associated immune deficiency in HIV patients are associated with an increased CVD risk ${ }^{(155)}$. Recent evidence that a low CD4 cell count was associated with an increased prevalence of carotid artery lesions in HIV patients further supports this finding ${ }^{(163)}$. Paradoxically, interruption of ART has been shown to increase CVD $\operatorname{risk}^{(174)}$, suggesting that HIV infection itself may play a role in increasing the risk of CVD. A recent treatment interruption trial in Thai HIVinfected patients demonstrated an association between markers of CVD, including increased vascular cell adhesion molecule-1, decreased adiponectin, and increased HIV RNA replication ${ }^{(175)}$, which further supports this finding.

Currently, risk-prediction models such as the Framingham score are recommended for use in estimating CVD risk $^{(162)}$. The Framingham equations, developed over a decade ago for use in non-HIV-infected individuals ${ }^{(176)}$, have been used to estimate CVD risk in HIV-infected subjects $^{(73,172,175)}$; however, studies assessing the accuracy of this model in HIV-infected patients are limited ${ }^{(177)}$. Friis-Møller et al. ${ }^{(118)}$, in a large prospective cohort, used CVD risk-scoring estimates for the general population to determine cut-offs to define HIV patients at 'high risk' of CVD. More recently, May et al. ${ }^{(178)}$ have developed another risk model for predicting the risk of MI or death from CHD in HIV-infected men. These researchers use data from five cardiovascular cohorts of HIV-uninfected men and adapt the model for the known risk factors observed in HIV patients following initiation of ART. However, the authors state that only a modest change in CHD risk factors may be detected using the risk model. In addition, the model does not take into account changes in CHD risk attributable to lifestyle changes. To the best of the current authors' knowledge, this model has also not yet been evaluated.

\section{Underlying molecular mechanisms}

\section{Altered adipocyte inflammatory status}

Studies of human adipose tissue from HIV-infected patients receiving ART have demonstrated an increase in the expression of genes relating to inflammation. In particular, HALS has been associated with an increase in pro-inflammatory cytokine expression ${ }^{(179)}$, in addition to increased systemic pro-inflammatory cytokine activity ${ }^{(180)}$. Increased circulating levels of TNF- $\alpha$, IL-6 and IL-1 $\beta$ have been shown in both in vitro ${ }^{(181,182)}$ and ex vivo studies $^{(180,183,184)}$. IL-6 has been shown to mediate insulin resistance and may modulate insulin signalling in adipose tissue $^{(185)}$. A large body of research has focused on the hypersecretion of TNF- $\alpha$, which has a number of pathophysiological effects including mediating insulin resistance via reduction of insulin receptor kinase activity, inducing apoptosis and lipolysis ${ }^{(186,187)}$, and down-regulating insulin receptor kinase substrate (IRS)-1 and GLUT-4 ${ }^{(186,188)}$. These effects may occur via a number of mechanisms including: a reduction in insulin signalling, attenuating the anti-lipolytic action of insulin(189); down-regulation of inhibitory G-protein-coupled receptors, leading to enhanced cyclic AMP levels ${ }^{(190)}$; down-regulation of lipoprotein lipase ${ }^{(186)}$; and down-regulation of the function and expression of perilipin, a lipid droplet-associated protein, which protects the adipocyte from the hydrolytic action of cellular lipases ${ }^{(191)}$. This increased cytokine production in HALS has also been suggested to induce a stress response in adipocytes, which may lead to physical damage of the cell ${ }^{(181,192)}$.

In addition to an increase in inflammatory cytokine production, HALS has been associated with a reduced expression of adiponectin in both plasma and adipose tissue $^{(193)}$. Adiponectin is a potent insulin sensitiser and, hence, its down-regulation contributes to insulin resistance $^{(182)}$. In vitro and ex vivo studies have shown reduced expression, secretion and release of adiponectin from adipose tissue ${ }^{(181,183)}$, while in vivo studies in HALS patients have identified the presence of hypoadiponectinaemia, which is a risk factor for cardiovascular impairment ${ }^{(194)}$. Inhibition of adipocyte differentiation, such as that caused by PI, has been shown to down-regulate adiponectin expression $^{(195)}$. Furthermore, down-regulation of adiponectin expression by NRTI has been suggested to occur as a result of the reduction in fat mass associated with NRTI use ${ }^{(196,197)}$. Mallewa et al. ${ }^{(188)}$ also refer to the negative feedback loop that exists between cytokines, whereby high levels of TNF- $\alpha$ and IL- 6 may inhibit the expression of adiponectin, which may also account for the observed reduction in adiponectin in HALS.

Adipose tissue macrophage infiltration, resulting in chronic low-grade inflammation, has also been suggested 
to contribute to the development of HALS ${ }^{(198)}$. Macrophage infiltration of adipose tissue has been shown to be greater in HALS patients compared with healthy controls ${ }^{(183)}$. Recently, Hammond et al. ${ }^{(179)}$ demonstrated an increase in adipose tissue macrophage count associated with thymidine NRTI treatment.

\section{Altered adipocyte functionality}

Microarray analysis of gene expression during adipogenesis has revealed numerous effects of ART on genes involved in adipocyte lipid and glucose metabolism ${ }^{(196)}$. In a recent study, Sievers et al ${ }^{(184)}$ showed that NRTI caused a general decrease in the expression of genes involved in adipocyte differentiation and lipid and glucose metabolism within the cell (CCAAT/enhancer-binding protein- $\alpha$ (C/EBPA), C/EBPB, cyclo-oxygenase-3 (COX3), GLUT4, hexokinase-1 (HEXOK1), perilipin (PLIN), $S R E B P 1 C)$, and an increase in markers of cell proliferation and genes involved in mitochondrial transcription (COX4, lamin-B (LAMINB), lamin A/C (LAMINA), proliferating cell nuclear antigen $(P C N A)$, PPAR- $\gamma$ co-activator-1b $(P G C 1 B))$.

Similarly, a number of in vitro studies have demonstrated changes in gene expression following exposure of adipocytes to antiretroviral drugs. Both PI and NRTI have been shown to down-regulate the expression of adipocyte differentiation genes such as Pparg, Cebpa, adiponectin (Adipoq), leptin (Lep), the scavenger receptor CD36 (Cd36), adipocyte lipid-binding protein-2 (Ap2), fatty acid synthase (fasn) and acetyl-coenzyme A carboxylase $(A C C)^{(196,199)}$. In particular, the NRTI $\mathrm{d} 4 \mathrm{~T}$ and ZDV have been found to cause a reduction in mRNA expression of adipogenic markers involved in lipid accumulation including fatty acid synthase, acetyl-coenzyme A carboxylase and adipocyte lipid-binding protein-2 ${ }^{(181,196,199,200)}$. Pacenti et al. ${ }^{(196)}$ demonstrated that NRTI modulate the expression of various transcription factors, such as Aebp1, Pou $5 f 1$ and $P h f \sigma$, which may play a role in determination of the adipocyte phenotype.

Adiponectin plays a role in glucose and lipid metabolism within the adipocyte ${ }^{(182)}$ and a number of in vitro studies have shown a reduction in adiponectin expression following exposure of 3T3-L1 murine and SimpsonGolabi-Behmel syndrome (SGBS) human adipocytes to $\mathrm{PI}^{(182,196,200)}$. These alterations in gene expression correspond with findings of altered adipocyte function including reduced capacity of insulin to activate lipogenesis ${ }^{(199)}$, decreased lipid accumulation ${ }^{(199)}$ and reduced adipocyte lipid content ${ }^{(181,182)}$.

Two ex vivo studies have investigated gene expression in subcutaneous adipose tissue samples from HALS patients and found reduced nuclear mRNA expression of mitochondrial proteins (PGC-1 $\alpha$ ), transcription factors (PPAR- $\gamma$ ) and adipocyte metabolic markers (GLUT-4, lipoprotein lipase $)^{(193,201)}$. Further support for these findings comes from results by Kim et al. ${ }^{(201)}$, which showed that the expression of PPAR- $\gamma$ increased after PI withdrawal. Moreover, mRNA expression of uncoupling protein-3 and preadipocyte factor-1, both inhibitors of adipocyte differentiation and metabolism, has been shown to be increased in HALS ${ }^{(193)}$. As with the work of Sievers et $a{ }^{(184)}$, these findings suggest that ART impair mitochondrial biogenesis, adipocyte differentiation and metabolism, and are involved in the down-regulation of adipogenic transcription factors.

\section{Mitochondrial toxicity}

ART-mediated inhibition of mitochondrial DNA-polymerase- $\gamma$, leading to mitochondrial toxicity, has been suggested to not only be involved in cell death and loss of fat mass, but in the aetiology of alterations in adipose tissue function ${ }^{(179)}$. As a result of these defects in adipose tissue function, the liver and skeletal muscles are exposed to increased concentrations of fatty acids, which has been associated with the development of the metabolic alterations seen in HALS ${ }^{(202)}$. Studies examining the effect of ART on mitochondrial toxicity are somewhat conflicting, with some showing limited or no effect of certain ART regimens on mitochondrial toxicity ${ }^{(203,204)}$, while others found effects for both single ART and cART ${ }^{(179,199,205)}$ According to Walker et $a l^{(206)}$, mitochondrial toxicity is sometimes more pronounced with use of cART. A recent study examining the effect of switching from d4T to tenofovir found improvements in mitochondrial toxicity after just 1 month ${ }^{(207)}$. Mallewa et al. ${ }^{(188)}$ suggest that these observed differences may be due to differing levels of affinity of the active metabolites of the drugs for mitochondrial DNA-polymerase- $\boldsymbol{\gamma}$. Furthermore, PI and NRTI have been associated with increased oxidative stress, which has been shown to induce mitochondrial dysfunction in 3T3F442A adipocytes ${ }^{(208,209)}$. This PI- and NRTI-associated mitochondrial dysfunction and oxidative stress have also been shown to trigger premature senescence in a number of cell models, including primary human fibroblasts ${ }^{(208)}$, human coronary artery endothelial cells and peripheral blood mononuclear cells ${ }^{(160)}$. In the context of HIV and ART, it has been suggested that premature senescence may contribute to accelerated cellular ageing, which might increase the risk of premature CVD as observed in HALS ${ }^{(160)}$.

\section{Treatment}

\section{Pharmacological and surgical management}

A number of pharmacological and surgical interventions have been used in the management of HALS. Pharmacological interventions include switching to more 'lipid-friendly' antiretrovirals ${ }^{(210)}$, use of synthetic growth hormone analogues to reduce excess visceral adipose tissue $^{(211)}$, statins to improve dyslipidaemia ${ }^{(212-214)}$ and 
anti-diabetic drugs ${ }^{(215-218)}$ to improve glucose abnormalities. A number of adverse events are associated with these pharmacological interventions, which range from drug-drug interactions ${ }^{(219)}$ to more serious side effects such as a higher virologic failure $e^{(220,221)}$ and increased risk of $\mathrm{MI}^{(222)}$ (Table 2).

To correct the morphological abnormalities associated with HALS, patients often undergo surgical procedures. These include liposuction ${ }^{(223)}$ and excisional lipectomy ${ }^{(224)}$ for LH and silicone gluteal prostheses ${ }^{(225)}$, facial fillers ${ }^{(226-228)}$, facial grafting ${ }^{(96)}$ and fat transplantation ${ }^{(229)}$ for LA. Surgical interventions such as these are radical interventions and are associated with numerous adverse events, which often offset their success (Table 2).

\section{Lifestyle interventions}

Although pharmacological and surgical interventions have a role to play in the management of HALS, lifestyle interventions are increasingly being trialled as first-line strategies in the management in HALS, due to their greater safety and tolerability.

\section{Exercise}

A number of studies have investigated the role of exercise in improving the systemic parameters in HALS and have shown mixed results. One study failed to show an effect of exercise and resistance training in improving lipid parameters in HALS ${ }^{(230)}$, while four have shown a beneficial effect, particularly in reducing central fat accumulation and in increasing body weight and limb girth ${ }^{(231-234)}$.
A recent cross-sectional study investigated the effect of leisure time physical activity on central fat accumulation in adults receiving ART and showed a significant negative correlation between leisure time physical activity and central fat ${ }^{(235)}$. As for the general population, exercise in HALS patients has proven effective in improving lipid parameters and insulin resistance. Yarasheski et al. ${ }^{(236)}$ investigated the effect of exercise on dyslipidaemia and showed that progressive weight-lifting reduced serum TAG levels in eighteen men receiving ART. Furthermore, a recent study of twenty men receiving supervised strength and endurance training demonstrated increases in insulin-mediated glucose uptake and hence improved insulin sensitivity after 16 weeks of training ${ }^{(237)}$. Overall, it appears that exercise has a beneficial effect in improving lipid parameters and central adiposity in HALS.

\section{Nutrition}

Relatively little is known about the influence of diet on the metabolic complications of HIV and associated lipodystrophy ${ }^{(238)}$. There are a number of studies that have generally investigated the area by cross-sectional analysis of diet and systemic parameters of HIV-positive adults with and without lipodystrophy. Dietary fibre intake has been shown to be positively associated with metabolic health in HIV-positive adults ${ }^{(40,41,43)}$. In another study, fibre had no association ${ }^{(239)}$. A recent Brazilian crosssectional study found that individuals with HIV who consumed more than two servings of dairy food per $\mathrm{d}$ had a lower BMI, waist circumference and blood pressure than those who consumed less than this amount ${ }^{(42)}$.

Table 2. Adverse events associated with the pharmacological and surgical management of the HIV-associated lipodystrophy syndrome

\begin{tabular}{|c|c|}
\hline Intervention & Associated adverse event(s) \\
\hline \multicolumn{2}{|l|}{ Pharmacological } \\
\hline \multicolumn{2}{|l|}{ Switch strategies } \\
\hline Switch from one PI to another, for example, atazanavir & Higher virologic failure ${ }^{(217)}$ \\
\hline Switch from PI to NRTI, for example, abacavir & Higher virologic failure ${ }^{(216)}$ \\
\hline \multicolumn{2}{|l|}{ Synthetic growth hormone analogues } \\
\hline $\begin{array}{l}\text { Growth hormone-releasing hormone: } \\
\text { tesamorelin }\left(\text { Egrifta }^{\mathrm{TM}} \text { ) }\right.\end{array}$ & $\begin{array}{l}\text { Arthralgia, erythema and pruritis at site of injection; } \\
\text { abdominal pain, swelling, myalgia; } \\
\text { worsening glycaemic control }\end{array}$ \\
\hline \multicolumn{2}{|l|}{ Lipid-lowering drugs } \\
\hline Statins & Pharmacokinetic interaction with $\mathrm{PI}^{(209,210,215)}$ \\
\hline Niacin & Glucose intolerance; transient increases in insulin resistance ${ }^{(248)}$ \\
\hline \multicolumn{2}{|l|}{ Anti-diabetic drugs } \\
\hline Metformin & Increased risk of lactic acidosis when taken with $\mathrm{NRTI}^{(213,214)}$ \\
\hline Rosiglitazone & Increased postprandial lipaemia; increased risk of myocardial infarction ${ }^{(214,218)}$ \\
\hline Pioglitazone & Pharmacokinetic interaction with $\mathrm{Pl}^{(214)}$ \\
\hline \multicolumn{2}{|l|}{ Surgical } \\
\hline \multicolumn{2}{|l|}{ Lipohypertrophy } \\
\hline Ultrasonic liposuction & Relapse/recurrence of abdominal lipohypertrophy common ${ }^{(219)}$ \\
\hline Excisional lipectomy & High rate of recurrence of dorsocervical fat pad ${ }^{(220)}$ \\
\hline \multicolumn{2}{|l|}{ Lipoatrophy } \\
\hline Silicone gluteal prostheses & Painful postoperative period ${ }^{(221)}$ \\
\hline Facial fillers & Granuloma formation; local migration of particles ${ }^{(90)}$ \\
\hline Fat transplantation & Operative risks and facial fat hypertrophy ${ }^{(225)}$ \\
\hline Facial grafting & Fat resorption ${ }^{(96)}$ \\
\hline
\end{tabular}

PI, protease inhibitor; NRTI, nucleoside RT inhibitor. 
The authors of this study suggest that Ca intake may be involved in mediating these changes. In most cross-sectional studies no association was found between saturated fat $^{(41,239,240)}$, total fat ${ }^{(41,239,240)}$ or other fat subclasses ${ }^{(239)}$, with the exception of trans-fatty acids ${ }^{(41)}$, and metabolic health in HIV-positive adults. Samaras et al. ${ }^{(241)}$ in their study of men with HALS showed that saturated fat intake was significantly positively associated with percentage body fat. Weak evidence suggests that polyunsaturated fat intake is positively associated with insulin sensitivity in HIV-infected individuals ${ }^{(43)}$. Contrary to these findings, Samaras et al. ${ }^{(241)}$ demonstrated that fat subtype did not relate to fasting insulin, insulin resistance, total cholesterol, HDL, TAG, glucose or adiponectin concentrations in HALS.

Turčinov et al. ${ }^{(45)}$ cross-sectionally investigated the diets of $136 \mathrm{HIV}$-positive Croatian adults on ART. Adherence to a Mediterranean diet was assessed by a 150 -item questionnaire and a point scale that stratified subjects as having low or moderate to high adherence. Although HALS was not an inclusion factor in the study, it was determined that Croatians who did not smoke and moderately or highly adhered to the Mediterranean diet were least likely to have LA and LH. In another cross-sectional study, adherence to a Mediterranean-style diet was positively correlated with HDL and marginally negatively correlated with TAG levels ${ }^{(44)}$.

Interestingly, a negative association between total and supplemental vitamin $\mathrm{E}$ intake and diastolic blood pressure has been shown among HIV-positive adults ${ }^{(239)}$. Two association studies have shown that dietary energy intake is not associated with metabolic dysregulation among HIV-positive adults ${ }^{(41,239)}$, and one has shown significant positive associations ${ }^{(240)}$.

A number of intervention studies have investigated the effects of diet in mitigating the metabolic and morphological abnormalities of HALS (Table 3). Barrios et al. ${ }^{(242)}$ showed that adherence to a low-fat diet for 6 months reduced total cholesterol by $10 \%$ and TAG by $23 \%$ among HIV-positive adults with hyperlipidaemia. Contrary to these findings, $\mathrm{Ng}$ et al. ${ }^{(243)}$ in a recent pilot randomised controlled trial found that HIV-infected individuals who adhered to a low-fat diet did not have reduced cholesterol levels and in fact had increased TAG levels after 1 year. The same authors found that HIV-infected individuals adopting a modified Mediterranean diet had significantly increased cholesterol levels after 9 and 12 months, while serum TAG levels in the same individuals remained unchanged over the same period ${ }^{(243)}$. In a case report, Roubenoff et $a l .^{(244)}$ found that a moderate-fat, low-GI, high-fibre diet, in combination with exercise, reduced total and trunk fat, LDL, fasting glucose and insulin resistance in one male HALS patient. Similarly, another study found that a low-fat diet and aerobic exercise significantly reduced body weight, body fat and waist:hip ratio in HALS patients ${ }^{(230)}$. One study investigated the effect of altering the fatty acid composition of the diet from medium- to long-chain fatty acids in HALS, and showed improvements in lipid profile after 3 months ${ }^{(245)}$. Owing to conflicting results, further randomised controlled trials are necessary before dietary recommendations can be made in this area.

A number of studies have examined the effect of supplements, such as L-acetylcarnitine, uridine and niacin, on the metabolic and morphological abnormalities in HALS. L-Acetylcarnitine has been suggested to be involved in regulating fatty acid oxidation ${ }^{(246)}$ and in one study of HALS subjects supplementation with $4 \mathrm{~g} / \mathrm{d}$ resulted in increased lipid oxidation, decreased intramyocellular TAG content, decreased plasma NEFA and lower insulin sensitivity compared with controls after 8 months ${ }^{(247)}$. Three interventions have trialled dietary uridine supplementation, which has been shown in vitro to prevent and treat mitochondrial toxicity ${ }^{(248)}$. One study showed no effect on changes in fat or blood mitochondrial DNA levels ${ }^{\text {(248) }}$, while the other two studies showed conflicting results one finding no significant increase in limb fat mass following 24 weeks of supplementation ${ }^{(249)}$, while the other showed a significant increase in subcutaneous fat mass following 3 months of supplementation in lipoatrophic patients ${ }^{(250)}$. Both studies used the same level of supplementation. Niacin, which has been shown to modulate lipoprotein metabolism and inhibit TAG synthesis ${ }^{(251)}$, was used in one study examining the effect of combination therapy with diet, exercise and niacin in patients with highly active ART-associated dyslipidaemia. Treatment with a low-saturated fat diet, exercise and niacin significantly increased HDL concentrations, and total cholesterol:HDL ratio compared with controls after 24 weeks ${ }^{(252)}$.

An interesting set of studies by Kosmiski et al. ${ }^{(253-255)}$ has shown that lipodystrophy in HIV is associated with an increase in resting energy expenditure (REE) per $\mathrm{kg}$ lean body mass. Furthermore, $3 \mathrm{~d}$ of eu-energetic feeding, which normally would not induce a change in REE, resulted in a significant increase in REE among HIV-positive adults with lipodystrophy compared with HIV-positive adults without lipodystrophy and healthy controls ${ }^{(253)}$. The same researchers found that $3 \mathrm{~d}$ of hypo-energetic feeding induced a significant drop in REE and $3 \mathrm{~d}$ of hyperenergetic feeding induced a significant increase in REE in HIV-positive adults with lipodystrophy compared with HIV-positive adults and healthy controls ${ }^{(253,255)}$. The group concluded that lipodystrophic subjects have higher REE per kg lean body mass than non-lipodystrophic subjects, that short-term over-feeding increases REE among lipodystrophic subjects and that short-term energy restriction reduces REE among lipodystrophic subjects. The authors suggest that hypermetabolism associated with lipodystrophy, and a form of adaptive thermogenesis invoked to dissipate energy that cannot be stored in a normal manner underlie these observations.

Despite weak support from observational studies, a number of intervention trials focusing on the role of $n-3$ 
Table 3. Intervention trials investigating the effect of nutrition in the HIV-associated lipodystrophy syndrome (HALS)

\begin{tabular}{|c|c|c|c|c|c|c|}
\hline Reference & Study design & $n$ & Subjects & Type of intervention & Duration & Outcome \\
\hline \multicolumn{7}{|l|}{ Diet } \\
\hline $\begin{array}{l}\text { Barrios et al. } \\
(2002)^{(242)}\end{array}$ & $\mathrm{PI}$ & 230 & HIV+, dyslipidaemic, receiving ART & Low-fat diet & 6 months & $\begin{array}{l}\text { TC, TAG and weight } \downarrow \text { significantly in } \\
\text { subjects with good compliance. Patients } \\
\text { receiving protease inhibitors had a } \\
\text { slightly greater decline in lipid levels than } \\
\text { those not on protease inhibitors }\end{array}$ \\
\hline $\begin{array}{l}\text { Kosmiski et al. } \\
(2007)^{(253)}\end{array}$ & CT & 28 & $\begin{array}{l}\text { HIV }+, 82 \% \mathrm{M} \text {, nine HALS +, ten } \\
\text { HALS - , nine healthy controls }\end{array}$ & $\begin{array}{l}3 \mathrm{~d} \text { eu-energetic feeding followed by } \\
3 \mathrm{~d} \text { overfeeding. }\end{array}$ & $6 d$ & $\begin{array}{l}\text { REE } \uparrow \text { significantly in HALS + but not } \\
\text { control groups }\end{array}$ \\
\hline $\begin{array}{l}\text { Kosmiski et al. } \\
(2007)^{(255)}\end{array}$ & CT & 30 & $\begin{array}{l}\text { HIV }+, 77 \% \mathrm{M} \text {, eleven HALS }+; \\
\text { ten HALS - (all receiving ART); } \\
\text { nine healthy controls }\end{array}$ & $\begin{array}{l}3 \mathrm{~d} \text { eu-energetic feeding followed by } \\
3 \mathrm{~d} \text { hypoenergetic feeding }\end{array}$ & $6 d$ & $\begin{array}{l}\text { REE significantly higher in HALS + com- } \\
\text { pared with HALS - and healthy } \\
\text { controls. Energy restriction caused } \\
\text { significant decline in REE in HALS + }\end{array}$ \\
\hline $\begin{array}{l}\mathrm{Ng} \text { et al. } \\
(2011)^{(243)}\end{array}$ & Pilot RCT & 48 & $\mathrm{HIV}+$ & $\begin{array}{l}\text { Modified Mediterranean diet } v \text {. } \\
\text { low-fat, low-cholesterol diet }\end{array}$ & 1 year & $\begin{array}{l}\text { Mediterranean diet: no change in TAG, } \\
\text { significant } \uparrow \text { serum TC } \\
\text { Low-fat diet: } \uparrow \text { TAG levels, no change in } \\
\text { TC }\end{array}$ \\
\hline $\begin{array}{l}\text { Roubenoff et al. } \\
(2002)^{(244)}\end{array}$ & CR & 1 & $\mathrm{HIV}+, \mathrm{M}$, receiving ART & $\begin{array}{l}\text { Moderate-fat, low-Gl, high-fibre diet } \\
+ \text { exercise three times per week }\end{array}$ & 4 months & $\begin{array}{l}\downarrow \text { Total and trunk fat, LDL, TC, fasting } \\
\text { glucose and insulin resistance }\end{array}$ \\
\hline $\begin{array}{l}\text { Terry et al. } \\
(2006)^{(230)}\end{array}$ & $\mathrm{RCT}$ & 30 & $\begin{array}{l}\text { HIV }+, 67 \% \text { M, HALS, receiving } \\
\text { ART }\end{array}$ & Low-lipid diet + aerobic exercise & 3 months & $\begin{array}{l}\text { Body weight, body fat and WHR } \downarrow \\
\text { significantly }\end{array}$ \\
\hline $\begin{array}{l}\text { Vázquez et al. } \\
(2006)^{(245)}\end{array}$ & $\mathrm{CR}$ & 1 & HIV+, M, HALS, receiving ART & $\begin{array}{l}\text { Eu-energetic substitution of MCT } \\
\text { for long-chain fatty acids }\end{array}$ & 3 months & $\begin{array}{l}\uparrow \text { Lean mass, } \downarrow \text { fat mass, improvement } \\
\text { in lipid profile }\end{array}$ \\
\hline $\begin{array}{l}\text { Wohl et al. } \\
(2005)^{(258)}\end{array}$ & OLRT & 26 & HIV+, hypertriacylglycerolaemic & $\begin{array}{l}\text { Diet ( } \downarrow \text { total and trans-fat, } \uparrow \text { fibre) } \\
\quad+\text { aerobic exercise }\end{array}$ & 16 weeks & Significant $\downarrow$ BMI at week 16 \\
\hline \multicolumn{7}{|l|}{ Supplements } \\
\hline $\begin{array}{l}\text { Benedini et al. } \\
(2009)^{(247)}\end{array}$ & RIT & 9 & $\begin{array}{l}\mathrm{HIV}+, 56 \% \mathrm{M} \text {, receiving protease } \\
\text { inhibitors/NRTI, nine healthy } \\
\text { controls }\end{array}$ & $2 \mathrm{~g} \mathrm{~L}$-acetylcarnitine per $\mathrm{d}$ & 8 months & $\begin{array}{l}\downarrow \text { Intramyocellular TAG content; } \downarrow \text { plasma } \\
\text { NEFA; } \downarrow \text { respiratory quotient; } \uparrow \% \text { leg } \\
\text { fat }\end{array}$ \\
\hline $\begin{array}{l}\text { Balasubramanyam } \\
\text { et al. }(2011)^{(252)}\end{array}$ & RDBPCT & 191 & HIV+, hypertriacylglycerolaemic & Diet + exercise + niacin $(2 \mathrm{~g} / \mathrm{d})$ & 24 weeks & Significant $\uparrow \mathrm{HDL}$ \\
\hline $\begin{array}{l}\text { Calmy et al. } \\
(2010)^{(249)}\end{array}$ & PR & 45 & $\mathrm{HIV}+, \mathrm{M}$, lipoatrophic patients & $36 \mathrm{~g}$ uridine t.d.s. & 24 weeks* & No significant $\uparrow$ in limb fat mass \\
\hline $\begin{array}{l}\text { McComsey et al. } \\
(2007)^{(248)}\end{array}$ & POL & 14 & $\begin{array}{l}\text { HIV }+, 79 \% \mathrm{M} \text {, receiving } \mathrm{ART} \text {, } \\
\text { lipoatrophic patients }\end{array}$ & $\begin{array}{l}36 \mathrm{~g} \text { NucleomaxX (uridine) t.d.s. } \\
\text { every other day }\end{array}$ & 32 weeks & $\begin{array}{l}\text { Lipoatrophy scores by patient and phys- } \\
\text { ician improved significantly at weeks } \\
16 \text { and } 32 \text { compared with baseline. } \\
\text { No changes in fat or blood mitochondrial } \\
\text { DNA levels }\end{array}$ \\
\hline $\begin{array}{l}\text { Sutinen et al. } \\
(2007)^{(250)}\end{array}$ & RDBPCT & 20 & $\begin{array}{l}\text { HIV }+, 85 \% \mathrm{M} \text {, ten cases, ten } \\
\text { controls, receiving ART, } \\
\text { lipoatrophic patients }\end{array}$ & $36 \mathrm{~g}$ uridine supplement t.d.s. & 3 months & $\begin{array}{l}\text { Significant } \uparrow \text { total limb fat, intra-abdominal } \\
\text { fat and total body fat from baseline to } \\
3 \text { months in intervention group. Non- } \\
\text { significant } \downarrow \text { in HDL in intervention } \\
\text { group }\end{array}$ \\
\hline
\end{tabular}

PI, prospective intervention; HIV +, HIV-positive; ART, antiretroviral therapy; TC, total cholesterol; $\downarrow$, decrease; CT, control trial; M, male; HALS + , HIV patients with HALS; HALS - , HIV patients without HALS; REE, resting energy expenditure; $\uparrow$, increase; RCT, randomised controlled trial; CR, case report; Gl, glycaemic index; WHR, waist:hip ratio; MCT, medium-chain TAG; OLRT, open-label randomised trial; RIT, randomised intervention trial; NRTI, nucleoside RT inhibitor; RDBPCT, randomised double-blind placebo-controlled trial; PR, prospective randomised trial; t.d.s., ter die sumendum (three times per d); POL, prospective open label study. * $10 \mathrm{~d}$ per month for 24 weeks.

†16-week intervention followed by 16 -week washout. 
long-chain PUFA ( $n$-3 LC-PUFA) in mitigating the metabolic abnormalities in HALS patients have been pursued. In the pre-ART era, intervention trials investigating the immunomodulatory effects of EPA and DHA as an adjunct therapy in HIV patients were pursued ${ }^{(256)}$. Their hypothesis was based on the immunomodulatory effects of EPA and DHA previously documented. Evidence strongly supports a role for $n$-3 LC-PUFA in HIV therapy, but in lipid lowering rather than immune regulation.

In a study of $120 \mathrm{HIV}$-positive adults on ART, 8 weeks of supplementation with $6 \mathrm{~g} n$-3 LC-PUFA per $\mathrm{d}$ induced a 25.5 and $38.7 \%$ reduction in plasma TAG concentrations among moderate and severe hypertriacylglycerolaemics, respectively ${ }^{(257)}$. Similarly, plasma TAG concentrations decreased by $25 \%$ following 4 weeks of supplementation with $1750 \mathrm{mg}$ EPA and $1150 \mathrm{mg}$ DHA per d among fifty-two HIV-positive adults with moderately raised $\mathrm{TAG}^{(258)}$. In a study of $100 \mathrm{HIV}$-positive adults with hypertriacylglycerolaemia, fish oil supplements taken at $6 \mathrm{~g} / \mathrm{d}$ for 8 weeks reduced TAG concentrations by $46 \%$, fenofibrates reduced TAG concentrations by $58 \%$, and the combination of fish oil and fenofibrates by $65 \cdot 5 \%{ }^{(259)}$. Manfredi et al. ${ }^{(260)}$ showed that rates of TAG normalisation were non-significantly different, at 25.9 and $34 \%$, between HIV-positive subjects with raised TAG supplemented with ethyl esters of $n-3$ LC-PUFA or treated with pharmaceutical lipid-lowering therapy, respectively. Salmon oil, administered at $3 \mathrm{~g} / \mathrm{d}$, significantly reduced TAG concentrations after 12 to 24 weeks of supplementation in fifty-eight HIV-positive adults on ART ${ }^{(261)}$. The TAG-lowering effects of the $n$-3 LC-PUFA among HIV-positive adults are supported by three smaller prospective studies ${ }^{(262-264)}$, although Virgili et al. ${ }^{(265)}$ showed no significant effect among nine HIV-positive subjects receiving $1120 \mathrm{mg}$ EPA and $720 \mathrm{mg}$ DHA daily for 6 weeks. A review of 237 hospital charts from HIV-positive adults with hypertriacylglycerolaemia showed that the use of $n$-3 LC-PUFA supplements was associated with a $32 \%$ reduction in TAG concentrations ${ }^{(26)}$. Furthermore, at baseline $11 \%$ of subjects used these dietary supplements, whereas at 6 months $25 \%$ of subjects used the supplements ${ }^{(266)}$. This demonstrates an enthusiasm and acceptance of these dietary supplements by HIV-positive adults with hypertriacylglycerolaemia. The effects of $n-3$ LC-PUFA on lipoprotein concentrations in HIV-positive adults are unclear, with no effect ${ }^{(262)}, 11 \%$ raised $\mathrm{HDL}^{(266)}$ and $22.4 \%$ raised $\mathrm{LDL}^{(258)}$ reported.

EPA and DHA have been shown to have anti-inflammatory effects in vitro via their role as PPAR- $\gamma$ ligands ${ }^{(267)}$ and modulation of the NF- $\kappa$ B signalling system ${ }^{(268,269)}$. Despite the strength of evidence to support anti-inflammatory effects of EPA and DHA in vitro, studies investigating the effects of $n$-3 LC-PUFA supplementation on cytokine production in HIV-positive adults are limited. One study found no effects on the concentration of the soluble TNF- $\alpha$ receptor following 6 months of dietary supplementation with a product containing $1.7 \mathrm{~g} n$-3 LC-PUFA and $7.4 \mathrm{~g}$ arginine ${ }^{(270)}$. Another study demonstrated that among ten subjects consuming a bar containing $1.96 \mathrm{~g}$ $n$-3 LC-PUFA, PGF-1 $\alpha$ secretion was decreased, and IL-1 $\beta$ and IL-6 secretion increased, from peripheral blood mononuclear cells ${ }^{(271)}$. Overall, n-3 LC-PUFA appear to have beneficial TAG-lowering effects; however, their role in modulating inflammation in HALS remains to be elucidated.

\section{Conclusion}

There is a clear disparity in the reported prevalence of HALS owing to lack of a standardised definition, use of different methods for diagnosing the syndrome, as well as variations in the study population. It has been suggested that the search for a standardised definition for HALS should be abandoned and instead replaced with a description of the non-infectious co-morbidities associated with $\mathrm{HIV}$, a condition that is slowly and globally acquiring chronic disease status. HALS is associated with fat maldistribution and metabolic complications such as dyslipidaemia, insulin resistance, hypertension, endothelial dysfunction and atherosclerosis, which lead to a rise in the incidence of CVD among this population group. Alterations in adipocyte inflammatory status and functionality, as well as mitochondrial toxicity, have been shown to underlie the development of HALS. Although current pharmacological and surgical interventions are effective in the treatment of HALS, their use is not without limitations. Targeted lifestyle interventions, such as exercise, may provide a useful alternative for managing non-infectious co-morbidities in HIV patients. Diet, particularly in the context of what we currently consider cardioprotective, appears to offer a safe, tolerable and effective treatment strategy for HALS, with evidence accumulating to supporting the use of $n-3$ LC-PUFA in future interventions.

\section{Acknowledgements}

The present review received no specific grant from any funding agency in the public, commercial or not-for-profit sectors. C. L. completed the review; A. M. advised in relation to the review content and approach and critically evaluated the manuscript. Both authors approved the final review. The authors declare no conflicts of interest.

\section{References}

1. Reynolds S \& Quinn T (2010) Setting the stage: current state of affairs and major challenges. Clin Infect Dis 50, Suppl. 3, S71-S76.

2. World Health Organization (2010) Fast facts on HIV. http:// www.who.int/hiv/data/fast_facts/en/index.html

3. Health Protection Agency (2010) HIV in the United Kingdom: 2010. http://www.hpa.org.uk/webc/HPAwebFile/ HPAweb_C/1287145367237 
4. Food and Drug Administration (2011) Antiretroviral drugs used in the treatment of HIV infection. http://www.fda gov/ForConsumers/ByAudience/ForPatientAdvocates/HIV andAIDSActivities/ucm118915.htm

5. de Béthune MP (2010) Non-nucleoside reverse transcriptase inhibitors (NNRTIs), their discovery, development, and use in the treatment of HIV-1 infection: a review of the last 20 years (1989-2009). Antiviral Res 85, 75-90.

6. McLeod GX \& Hammer SM (1992) Treatment of HIV infection: the antiretroviral nucleoside analogues. Nucleoside analogues: combination therapy. Hosp Pract 27, 14-25.

7. Shafer RW \& Vuitton DA (1999) Highly active antiretroviral therapy (HAART) for the treatment of infection with human immunodeficiency virus type 1. Biomed Pharmacother 53, 73-86.

8. De Clercq E (1998) The role of non-nucleoside reverse transcriptase inhibitors (NNRTIs) in the therapy of HIV-1 infection. Antiviral Res 38, 153-179.

9. Kakuda TN (2000) Pharmacology of nucleoside and nucleotide reverse transcriptase inhibitor-induced mitochondrial toxicity. Clin Ther 22, 685-708.

10. Gilead Sciences Inc. (2001) VIREAD (tenofovir): highlights of prescribing information. http://www.gilead.com/pdf/ viread_pi.pdf

11. Wynn GH, Zapor MJ, Smith BH, et al. (2004) Antiretrovirals, part 1: overview, history, and focus on protease inhibitors. Psychosomatics 45, 262-270.

12. Greenberg ML \& Cammack N (2004) Resistance to enfuvirtide, the first HIV fusion inhibitor. J Antimicrob Chemother 54, 333-340.

13. Dorr P, Westby M, Dobbs S, et al. (2005) Maraviroc (UK-427,857), a potent, orally bioavailable, and selective small-molecule inhibitor of chemokine receptor CCR5 with broad-spectrum anti-human immunodeficiency virus type 1 activity. Antimicrob Agents Ch 49, 4721-4732.

14. De Clercq E (2010) Antiretroviral drugs. Curr Opin Pharmacol 10, 507-515.

15. Dubé MP, Johnson DL, Currier JS, et al. (1997) Protease inhibitor-associated hyperglycaemia. Lancet 350, 713-714.

16. Deeks SG (1997) HIV-1 protease inhibitors. A review for clinicians. JAMA 227, 145-153.

17. Hengel RL, Watts NB \& Lennox JL (1997) Benign symmetric lipomatosis associated with protease inhibitors. Lancet $\mathbf{3 5 0}$, 1596.

18. Roth VR, Kravcik S \& Angel JB (1998) Development of cervical fat pads following therapy with human immunodeficiency virus type 1 protease inhibitors. Clin Infect Dis 27, 65-67.

19. Viraben R \& Aquilina C (1998) Indinavir-associated lipodystrophy. AIDS 12, F37-F39.

20. Carr A, Samaras K, Burton S, et al. (1998) A syndrome of peripheral lipodystrophy, hyperlipidaemia and insulin resistance in patients receiving HIV protease inhibitors. AIDS 12, F51-F58.

21. Mallon PW (2007) Pathogenesis of lipodystrophy and lipid abnormalities in patients taking antiretroviral therapy. AIDS Rev 9, 3-15.

22. Omolayo O \& Sealy PL (2008) HIV lipodystrophy syndrome. Hosp Physician 44, 7-14.

23. Lichtenstein K, Balasubramanyam A, Sekhar R, et al. (2007) HIV-associated adipose redistribution syndrome (HARS): definition, epidemiology and clinical impact. AIDS Res Ther $4,16$.

24. Worm SW, Friis-Møller N, Bruyand M, et al. (2010) High prevalence of the metabolic syndrome in HIV-infected patients: impact of different definitions of the metabolic syndrome. AIDS 24, 427-435.
25. Samaras K, Wand H, Law M, et al. (2007) Prevalence of metabolic syndrome in HIV-infected patients receiving highly active antiretroviral therapy using International Diabetes Foundation and Adult Treatment Panel III criteria. Diabetes Care 30, 113-119.

26. Lumpkin MM (1997) Reports of diabetes and hyperglycemia in patients receiving protease inhibitors for the treatment of human immunodeficiency virus (HIV). http://www.fda.gov/ ForConsumers/ByAudience/ForPatientAdvocates/HIVand AIDSActivities/ucm151115.htm

27. Behrens G, Dejam A, Schmidt H, et al. (1999) Impaired glucose tolerance, $\beta$ cell function and lipid metabolism in HIV patients under treatment with protease inhibitors. AIDS 13, F63-F70.

28. Brown TT, Cole SR, Li X, et al. (2005) Antiretroviral therapy and the prevalence and incidence of diabetes mellitus in the Multicenter AIDS Cohort Study. Arch Intern Med 165, 1179-1184.

29. Masiá M, Padilla S, García N, et al. (2010) Endothelial function is impaired in HIV-infected patients with lipodystrophy. Antivir Ther 15, 101-110.

30. Friis-Møller N, Sabin CA, Weber R, et al. (2003) Combination antiretroviral therapy and the risk of myocardial infarction. $N$ Engl J Med 349, 1993-2003.

31. Salyer J, Lyon DE, Settle J, et al. (2006) Coronary heart disease risks and lifestyle behaviors in persons with HIV infection. $J$ Assoc Nurses AIDS Care 17, 3-17.

32. Mondy K, Overton E, Grubb J, et al. (2007) Metabolic syndrome in HIV-infected patients from an urban, midwestern US outpatient population. Clin Infect Dis 44, 726-734.

33. Vittecoq D, Escaut L, Chironi G, et al. (2003) Coronary heart disease in HIV-infected patients in the highly active antiretroviral treatment era. AIDS 17, Suppl. 1, S70-S76.

34. Matetzky S, Domingo M, Kar S, et al. (2003) Acute myocardial infarction in human immunodeficiency virus-infected patients. Arch Intern Med 163, 457-460.

35. Bozzette SA, Ake CF, Tam HK, et al. (2008) Long-term survival and serious cardiovascular events in HIV-infected patients treated with highly active antiretroviral therapy. J Acquir Immune Defic Syndr 47, 338-341.

36. Khunnawat C, Mukerji S, Havlichek D Jr, et al. (2008) Cardiovascular manifestations in human immunodeficiency virus-infected patients. Am J Cardiol 102, 635-642.

37. Friis-Møller N, Thiébaut R, Reiss P, et al. (2010) Predicting the risk of cardiovascular disease in HIV-infected patients: the data collection on adverse effects of anti-HIV drugs study. Eur J Cardiovasc Prev Rehabil 17, 491-501.

38. Guaraldi G, Zona S, Alexopoulos N, et al. (2009) Coronary aging in HIV-infected patients. Clin Infect Dis 49, 1756-1762.

39. American Dietetic Association (2010) Position of the American Dietetic Association: nutrition intervention and human immunodeficiency virus infection. J Am Diet Assoc 110, 1105-1119.

40. Hendricks KM, Dong KR, Tang AM, et al. (2003) High-fiber diet in HIV-positive men is associated with lower risk of developing fat deposition. Am J Clin Nutr 78, 790-795.

41. Shah M, Tierney K, Adams-Huet B, et al. (2005) The role of diet, exercise and smoking in dyslipidaemia in HIV-infected patients with lipodystrophy. HIV Med 6, 291-298.

42. Leite LHM \& Sampaio ABMM (2010) Dietary calcium, dairy food intake and metabolic abnormalities in HIV-infected individuals. J Hum Nutr Diet 23, 535-543.

43. Hadigan C, Jeste S, Anderson EJ, et al. (2001) Modifiable dietary habits and their relation to metabolic abnormalities in men and women with human immunodeficiency virus infection and fat redistribution. Clin Infect Dis 33, 710-717. 
44. Tsiodras S, Poulia K-A, Yannakoulia M, et al. (2009) Adherence to Mediterranean diet is favorably associated with metabolic parameters in HIV-positive patients with the highly active antiretroviral therapy-induced metabolic syndrome and lipodystrophy. Metabolism 58, 854-859.

45. Turčinov D, Stanley C, Rutherford G, et al. (2009) Adherence to the Mediterranean diet is associated with a lower risk of body-shape changes in Croatian patients treated with combination antiretroviral therapy. Eur $J$ Epidemiol 24, 267-274.

46. Jacobson DL, Tang AM, Spiegelman D, et al. (2006) Incidence of metabolic syndrome in a cohort of HIVinfected adults and prevalence relative to the US population (National Health and Nutrition Examination Survey). J Acquir Immune Defic Syndr 43, 458-466.

47. Sobieszczyk ME, Hoover DR, Anastos K, et al. (2008) Prevalence and predictors of metabolic syndrome among HIV-infected and HIV-uninfected women in the Women's Interagency HIV Study. J Acquir Immune Defic Syndr 48, $272-280$.

48. Tien PC, Cole SR, Williams CM, et al. (2003) Incidence of lipoatrophy and lipohypertrophy in the Women's Interagency HIV Study. J Acquir Immune Defic Syndr 34, 461-466.

49. Norris A \& Dreher HM (2004) Lipodystrophy syndrome: the morphologic and metabolic effects of antiretroviral therapy in HIV infection. J Assoc Nurses AIDS Care 15, 46-64.

50. Benn P, Ruff C, Cartledge J, et al. (2003) Overcoming subjectivity in assessing facial lipoatrophy: is there a role for three-dimensional laser scans? HIV Med 4, 325-331.

51. Carter V, Hoy J, Bailey M, et al. (2001) The prevalence of lipodystrophy in an ambulant HIV-infected population: it all depends on the definition. HIV Med 2, 174-180.

52. Boufassa FDA, Lascaux AS, Meyer L, et al. (2001) Lipodystrophy in $685 \mathrm{HIV}$-1-treated patients: influence of antiretroviral treatment and immunovirological response. HIV Clin Trials 2, 339-345.

53. Chêne G, Angelini E, Cotte L, et al. (2002) Role of long-term nucleoside-analogue therapy in lipodystrophy and metabolic disorders in human immunodeficiency virus-infected patients. Clin Infect Dis 34, 649-657.

54. Galli M, Cozzi-Lepri A, Ridolfo AL, et al. (2002) Incidence of adipose tissue alterations in first-line antiretroviral therapy: The LipoICoNa Study. Arch Intern Med 162, 2621-2628.

55. Galli M, Veglia F, Angarano G, et al. (2003) Gender differences in antiretroviral drug-related adipose tissue alterations: women are at higher risk than men and develop particular lipodystrophy patterns. J Acquir Immune Defic Syndr 34, 58-61.

56. Miller J, Carr A, Emery S, et al. (2003) HIV lipodystrophy: prevalence, severity and correlates of risk in Australia. HIV Med 4, 293-301.

57. Puttawong S, Prasithsirikul W \& Vadcharavivad S (2004) Prevalence of lipodystrophy in Thai-HIV infected patients. J Med Assoc Thai 87, 605-611.

58. Young J, Rickenbach M, Weber R, et al. (2005) Body fat changes among antiretroviral-naive patients on PI- and NNRTI-based HAART in the Swiss HIV Cohort Study. Antivir Ther 10, 73-81.

59. Mutimura EM, Stewart AP, Rheeder PMD, et al. (2007) Metabolic function and the prevalence of lipodystrophy in a population of HIV-infected African subjects receiving highly active antiretroviral therapy. $J$ Acquir Immune Defic Syndr 46, 451-455.

60. Nguyen A, Calmy A, Schiffer V, et al. (2008) Lipodystrophy and weight changes: data from the Swiss HIV Cohort Study, 2000-2006. HIV Med 9, 142-150.
61. Seminari E, Tinelli C, Minoli L, et al. (2002) Evaluation of the risk factors associated with lipodystrophy development in a cohort of HIV-positive patients. Antivir Ther 7, $175-180$.

62. Kalyanasundaram AP, Jacob SM, Hemalatha R, et al. (2012) Prevalence of lipodystrophy and dyslipidemia among patients with HIV infection on generic ART in Rural South India. J Int Assoc Physicians AIDS Care (Chic) 11, 329-334.

63. Saint-Marc T, Partisani M, Poizot-Martin I, et al. (2000) Fat distribution evaluated by computed tomography and metabolic abnormalities in patients undergoing antiretroviral therapy: preliminary results of the LIPOCO study. AIDS 14, 37-49.

64. Thiébaut R, Daucourt V, Mercié P, et al. (2000) Lipodystrophy, metabolic disorders, and human immunodeficiency virus infection: Aquitaine Cohort, France, 1999. Clin Infect Dis 31, 1482-1487.

65. Lichtenstein KA, Ward DJ, Moorman AC, et al. (2001) Clinical assessment of HIV-associated lipodystrophy in an ambulatory population. AIDS 15, 1389-1398.

66. Heath KV, Singer J, O'Shaughnessy MV, et al. (2002) Intentional nonadherence due to adverse symptoms associated with antiretroviral therapy. J Acquir Immune Defic Syndr 31, 211-217.

67. Mauss S, Corzillius M, Wolf E, et al. (2002) Risk factors for the HIV-associated lipodystrophy syndrome in a closed cohort of patients after 3 years of antiretroviral treatment. HIV Med 3, 49-55.

68. Paton NI, Earnest A, Ng YM, et al. (2002) Lipodystrophy in a cohort of human immunodeficiency virus-infected Asian patients: prevalence, associated factors, and psychological impact. Clin Infect Dis 35, 1244-1249.

69. Lichtenstein KA, Delaney KM, Armon C, et al. (2003) Incidence of and risk factors for lipoatrophy (abnormal fat loss) in ambulatory HIV-1-infected patients. J Acquir Immune Defic Syndr 32, 48-56.

70. Pujari SN, Dravid AM, Naik E, et al. (2005) Lipodystrophy and dyslipidemia among patients taking first-line, World Health Organization-recommended highly active antiretroviral therapy regimens in Western India. J Acquir Immune Defic Syndr 39, 199-202.

71. van Griensven J, De Naeyer L, Mushi T, et al. (2007) High prevalence of lipoatrophy among patients on stavudinecontaining first-line antiretroviral therapy regimens in Rwanda. Trans R Soc Trop Med Hyg 101, 793-798.

72. Walmsley S, Cheung A, Fantus G, et al. (2008) A prospective study of body fat redistribution, lipid, and glucose parameters in HIV-infected patients initiating combination antiretroviral therapy. HIV Clin Trials 9, 314-323.

73. Jevtovic D, Dragovic G, Salemovic D, et al. (2009) The metabolic syndrome, an epidemic among HIV-infected patients on HAART. Biomed Pharmacother 63, 337-342.

74. Mercier S, Gueye NFN, Cournil A, et al. (2009) Lipodystrophy and metabolic disorders in HIV-1-infected adults on 4- to 9-year antiretroviral therapy in Senegal: a case-control study. J Acquir Immune Defic Syndr 51, 224-230.

75. Zannou DM, Denoeud L, Lacombe K, et al. (2009) Incidence of lipodystrophy and metabolic disorders in patients starting non-nucleoside reverse transcriptase inhibitors in Benin. Antivir Ther 14, 371-380.

76. Gervasoni C, Ridolfo AL, Trifiro G, et al. (1999) Redistribution of body fat in HIV-infected women undergoing combined antiretroviral therapy. AIDS 13, 465-471.

77. Goujard C, Boufassa F, Deveau C, et al. (2001) Incidence of clinical lipodystrophy in HIV-1-infected patients treated during primary infection. AIDS 15, 282-284. 
78. Heath KV, Hogg RS, Chan KJ, et al. (2001) Lipodystrophyassociated morphological, cholesterol and triglyceride abnormalities in a population-based HIV/AIDS treatment database. AIDS 15, 231-239.

79. Martínez E, Mocroft A, García-Viejo MA, et al. (2001) Risk of lipodystrophy in HIV-1-infected patients treated with protease inhibitors: a prospective cohort study. Lancet 357, 592-598.

80. Bernasconi E, Boubaker K, Junghans C, et al. (2002) Abnormalities of body fat distribution in HIV-infected persons treated with antiretroviral drugs: The Swiss HIV Cohort Study. J Acquir Immune Defic Syndr 31, 50-55.

81. Savès M, Raffi F, Capeau J, et al. (2002) Factors related to lipodystrophy and metabolic alterations in patients with human immunodeficiency virus infection receiving highly active antiretroviral therapy. Clin Infect Dis 34, 1396-1405.

82. Carr A, Emery S, Law M, et al. (2003) An objective case definition of lipodystrophy in HIV-infected adults: a case-control study. Lancet 361, 726-735.

83. Galli M, Ridolfo AL, Adorni F, et al. (2003) Correlates of risk of adipose tissue alterations and their modifications over time in HIV-1-infected women treated with antiretroviral therapy. Antivir Ther 8, 347-354.

84. Fellay J, Ledergerber B, Bernasconi E, et al. (2001) Prevalence of adverse events associated with potent antiretroviral treatment: Swiss HIV Cohort Study. Lancet 358, 1322-1327.

85. van der Valk M, Gisolf EH, Reiss P, et al. (2001) Increased risk of lipodystrophy when nucleoside analogue reverse transcriptase inhibitors are included with protease inhibitors in the treatment of HIV-1 infection. AIDS 15, 847-855.

86. National Cholesterol Education Program (NCEP) Expert Panel on Detection, Evaluation, and Treatment of High Blood Cholesterol in Adults (Adult Treatment Panel III) (2002) Third Report of the National Cholesterol Education Program (NCEP) Expert Panel on Detection, Evaluation, and Treatment of High Blood Cholesterol in Adults (Adult Treatment Panel III) final report. Circulation 106, 3143-3421.

87. Jericó C, Knobel H, Montero M, et al. (2005) Metabolic syndrome among HIV-infected patients: prevalence, characteristics, and related factors. Diabetes Care 28, 132-137.

88. Elgalib A, Aboud M, Kulasegaram R, et al. (2011) The assessment of metabolic syndrome in UK patients with HIV using two different definitions: CREATE 2 study. Curr Med Res Opin 27, 63-69.

89. International Diabetes Federation (2005) Global guideline for type 2 diabetes. http://www.idf.org/Global_guideline

90. Gkrania-Klotsas E \& Klotsas A-E (2007) HIV and HIV treatment: effects on fats, glucose and lipids. Br Med Bull $\mathbf{8 4}$, 49-68.

91. Grundy SM, Brewer HB Jr, Cleeman JI, et al. (2004) Definition of metabolic syndrome: report of the National Heart, Lung, and Blood Institute/American Heart Association conference on scientific issues related to definition. Circulation 109, 433-438.

92. US National Institutes of Health (2004) DAIDS HIV Vaccines and Research Program NIoH. Division of AIDS (DAIDS) revised toxicity tables for grading the severity of adult and pediatric adverse events experiences, version 1.0. Washington, DC. http://www.ucdmc.ucdavis. edu/clinicaltrials/documents/DAIDS_AE_GradingTable_Final Dec2004.pdf

93. Han SH, Zhou J, Saghayam S, et al. (2011) Prevalence of and risk factors for lipodystrophy among HIV-infected patients receiving combined antiretroviral treatment in the Asia-Pacific region: results from the TREAT Asia HIV Observational Database (TAHOD). Endocr J 58, 475-484.
94. Wanke C, Polsky B \& Kotler D (2002) Guidelines for using body composition measurement in patients with human immunodeficiency virus infection. AIDS Patient Care STDS 16, 375-388.

95. Carr A, Law M \& HIV Lipodystrophy Case Definition Study Group (2003) An objective lipodystrophy severity grading scale derived from the lipodystrophy case definition score. J Acquir Immune Defic Syndr 33, 571-576.

96. Fontdevila J, Serra-Renom JM, Raigosa M, et al. (2008) Assessing the long-term viability of facial fat grafts: an objective measure using computed tomography. Aesthet Surg J 28, 380-386.

97. Guaraldi G \& Baraboutis I (2009) Evolving perspectives on HIV-associated lipodystrophy syndrome: moving from lipodystrophy to non-infectious HIV co-morbidities. J Antimicrob Chemother 64, 437-440.

98. Carr A, Samaras K, Thorisdottir A, et al. (1999) Diagnosis, prediction, and natural course of HIV-1 protease-inhibitorassociated lipodystrophy, hyperlipidaemia, and diabetes mellitus: a cohort study. Lancet 353, 2093-2099.

99. Safrin S \& Grunfeld C (1999) Fat distribution and metabolic changes in patients with HIV infection. AIDS 13, 2493-2505.

100. Saint-Marc T, Partisani M, Poizot-Martin I, et al. (1999) A syndrome of peripheral fat wasting (lipodystrophy) in patients receiving long-term nucleoside analogue therapy. AIDS 13, 1659-1667.

101. Grinspoon S, Corcoran C, Miller K, et al. (1997) Body composition and endocrine function in women with acquired immunodeficiency syndrome wasting. J Clin Endocrinol Metab 82, 1332-1337.

102. Engelson ES, Kotler DP, Tan Y, et al. (1999) Fat distribution in HIV-infected patients reporting truncal enlargement quantified by whole-body magnetic resonance imaging. Am J Clin Nutr 69, 1162-1169.

103. Bergersen B, Sandvik L, Ellingsen I, et al. (2005) Lipoatrophic men 44 months after the diagnosis of lipoatrophy are less lipoatrophic but more hypertensive. HIV Med $\mathbf{6}$, 260-267.

104. Nolan D, Hammond E, James I, et al. (2003) Contribution of nucleoside-analogue reverse transcriptase inhibitor therapy to lipoatrophy from the population to the cellular level. Antivir Ther 8, 617-626.

105. Grinspoon S \& Carr A (2005) Cardiovascular risk and body-fat abnormalities in HIV-infected adults. $N$ Engl $J$ Med 352, 48-62.

106. Jacobson DL, Knox T, Spiegelman D, et al. (2005) Prevalence of, evolution of, and risk factors for fat atrophy and fat deposition in a cohort of HIV-infected men and women. Clin Infect Dis 40, 1837-1845.

107. Miller KD, Jones E, Yanovski JA, et al. (1998) Visceral abdominal-fat accumulation associated with use of indinavir. Lancet 351, 871-875.

108. Dinges WL, Chen D, Snell PG, et al. (2005) Regional body fat distribution in HIV-infected patients with lipodystrophy. J Investig Med 53, 15-25.

109. Lo JC, Mulligan K, Tai VW, et al. (1998) "Buffalo hump" in men with HIV-1 infection. Lancet 351, 867-870.

110. Palella FJ Jr, Chmiel JS, Riddler SA, et al. (2006) A novel pattern of lipoaccumulation in HIV-infected men. JAMA 296, $766-768$.

111. Guaraldi G, Orlando G, Squillace N, et al. (2007) Prevalence of and risk factors for pubic lipoma development in HIV-infected persons. J Acquir Immune Defic Syndr 45, $72-76$.

112. Cooper DA, Cordery DV, Reiss P, et al. (2011) The effects of enfuvirtide therapy on body composition and metabolic 
parameters over 48 weeks in the TORO body imaging substudy. HIV Med 12, 31-39.

113. Grunfeld C, Kotler DP, Hamadeh R, et al. (1989) Hypertriglyceridemia in acquired immunodeficiency syndrome. Am J Med 86, 27-31.

114. Grunfeld C, Kotler DP, Shigenaga JK, et al. (1991) Circulating interferon- $\alpha$ levels and hypertriglyceridemia in the acquired immunodeficiency syndrome. Am J Med 90, 154-162.

115. Riddler SA, Smit E, Cole SR, et al. (2003) Impact of HIV infection and HAART on serum lipids in men. JAMA 289, $2978-2982$.

116. Tomažič J, Silič A, Karner P, et al. (2004) Lipodystrophy and metabolic abnormalities in Slovenian HIV-infected patients. Wien Klin Wochenschr 116, 755-759.

117. Lesi OA, Soyebi KS \& Eboh CN (2009) Fatty liver and hyperlipidemia in a cohort of HIV-positive Africans on highly active antiretroviral therapy. J Natl Med Assoc 101, 151-155.

118. Friis-Møller N, Weber R, Reiss P, et al. (2003) Cardiovascular disease risk factors in HIV patients - association with antiretroviral therapy. Results from the DAD study. AIDS 17, 1179-1193.

119. Carr A, Samaras K, Chisholm DJ, et al. (1998) Pathogenesis of HIV-1-protease inhibitor-associated peripheral lipodystrophy, hyperlipidaemia, and insulin resistance. Lancet 351, 1881-1883.

120. Periard D, Telenti A, Sudre P, et al. (1999) Atherogenic dyslipidemia in HIV-infected individuals treated with protease inhibitors. Circulation 100, 700-705.

121. van Leth F, Phanuphak P, Stroes E, et al. (2004) Nevirapine and efavirenz elicit different changes in lipid profiles in antiretroviral-therapy-naive patients infected with HIV-1. PLoS Med 1, e19.

122. Jones R, Sawleshwarkar S, Michailidis C, et al. (2005) Impact of antiretroviral choice on hypercholesterolaemia events: the role of the nucleoside reverse transcriptase inhibitor backbone. HIV Med 6, 396-402.

123. Kosmiski LA, Miller HL \& Klemm DJ (2006) In combination, nucleoside reverse transcriptase inhibitors have significant effects on 3T3-L1 adipocyte lipid accumulation and survival. Antivir Ther 11, 187-195.

124. Ware LJ, Jackson AG, Wootton SA, et al. (2009) Antiretroviral therapy with or without protease inhibitors impairs postprandial TAG hydrolysis in HIV-infected men. $\mathrm{Br} J$ Nutr. 102, 1038-1046.

125. Monnerat BZ, Cerutti Junior C, Caniçali SC, et al. (2008) Clinical and biochemical evaluation of HIV-related lipodystrophy in an ambulatory population from the Hospital Universitário Cassiano Antonio de Morais, Vitória, ES, Brazil. Braz J Infect Dis 12, 364-368.

126. Pernerstorfer-Schoen H, Jilma B, Perschler A, et al. (2001) Sex differences in HAART-associated dyslipidaemia. AIDS 15, 725-734.

127. Gaillard T, Schuster D \& Osei K (2009) Metabolic syndrome in black people of the African diaspora: the paradox of current classification, definition and criteria. Ethn Dis 19, Suppl. 2, S2-1-S2-7.

128. Foulkes AS, Wohl DA, Frank I, et al. (2006) Associations among race/ethnicity, ApoC-III genotypes, and lipids in HIV-1-infected individuals on antiretroviral therapy. PLoS Med 3, e52.

129. Guardiola M, Ferré R, Salazar J, et al. (2006) Protease inhibitor-associated dyslipidemia in HIV-infected patients is strongly influenced by the APOA5-1131T $\rightarrow \mathrm{C}$ gene variation. Clin Chem 52, 1914-1919.

130. Fauvel J, Bonnet E, Ruidavets J-B, et al. (2001) An interaction between apo C-III variants and protease inhibitors contributes to high triglyceride/low HDL levels in treated HIV patients. AIDS 15, 2397-2406.

131. Miserez AR, Muller PY, Barella L, et al. (2001) A singlenucleotide polymorphism in the sterol-regulatory elementbinding protein 1c gene is predictive of HIV-related hyperlipoproteinaemia. AIDS 15, 2045-2049.

132. Nolan D, Moore C, Castley A, et al. (2003) Tumour necrosis factor- $\alpha$ gene $-238 \mathrm{G} / \mathrm{A}$ promoter polymorphism associated with a more rapid onset of lipodystrophy. AIDS 17, 121-123.

133. Tarr Philip E, Taffé P, Bleiber G, et al. (2005) Modeling the influence of APOC3, APOE, and TNF polymorphisms on the risk of antiretroviral therapy-associated lipid disorders. J Infect Dis 191, 1419-1426.

134. Abourizk NN, Lyons RW \& Madden GM (1993) Transient state of NIDDM in a patient with AIDS. Diabetes Care 16, 931-933.

135. Bradbury RA \& Samaras K (2008) Antiretroviral therapy and the human immunodeficiency virus - improved survival but at what cost? Diabetes Obes Metab 10, 441-450.

136. Eastone JA \& Decker CA (1997) New-onset diabetes mellitus associated with use of protease inhibitor. Ann Intern Med 127, 948.

137. Visnergarwala F, Krause KL \& Musher DM (1997) Severe diabetes associated with protease inhibitors. Ann Intern Med 127, 947.

138. van Dieren S, Beulens JWJ, van der Schouw YT, et al. (2010) The global burden of diabetes and its complications: an emerging pandemic. Eur J Cardiovasc Prev Rehabil 17, Suppl. 1, s3-s8.

139. Danaei G, Finucane MM, Lu Y, et al. (2011) National, regional, and global trends in fasting plasma glucose and diabetes prevalence since 1980: systematic analysis of health examination surveys and epidemiological studies with 370 country-years and $2 \cdot 7$ million participants. Lancet 378, 31-40.

140. Carr A, Hudson J, Chuah J, et al. (2001) HIV protease inhibitor substitution in patients with lipodystrophy: a randomized, controlled, open-label, multicentre study. AIDS 15, 1811-1822.

141. Dubé MP, Parker RA, Tebas P, et al. (2005) Glucose metabolism, lipid, and body fat changes in antiretroviral-naive subjects randomized to nelfinavir or efavirenz plus dual nucleosides. AIDS 19, 1807-1818.

142. Srivanich N, Ngarmukos C \& Sungkanuparph S (2010) Prevalence of and risk factors for pre-diabetes in HIV-1infected patients in Bangkok, Thailand. J Int Assoc Physicians AIDS Care 9, 358-361.

143. Lee GA, Seneviratne T, Noor MA, et al. (2004) The metabolic effects of lopinavir/ritonavir in HIV-negative men. AIDS 18, 641-649.

144. Woerle H, Mariuz PR, Meyer C, et al. (2003) Mechanisms for the deterioration in glucose tolerance associated with HIV protease inhibitor regimens. Diabetes 52, 918-925.

145. Tien PC, Schneider MF, Cole SR, et al. (2007) Antiretroviral therapy exposure and incidence of diabetes mellitus in the Women's Interagency HIV Study. AIDS 21, $1739-1745$.

146. American Diabetes Association, Expert Committee on the Diagnosis and Classification of Diabetes Mellitus (2003) Report of the Expert Committee on the Diagnosis and Classification of Diabetes Mellitus. Diabetes Care 26, Suppl. 1, S5-S20.

147. Wohl DA, McComsey G, Tebas P, et al. (2006) Current concepts in the diagnosis and management of metabolic complications of HIV infection and its therapy. Clin Infect Dis 43, 645-653. 
148. Crane HM, Grunfeld C, Harrington RD, et al. (2009) Lipoatrophy and lipohypertrophy are independently associated with hypertension. HIV Med 10, 496-503.

149. de Arruda Junior ER, Lacerda HR, Moura LCRV, et al. (2010) Risk factors related to hypertension among patients in a cohort living with HIV/AIDS. Braz J Infect Dis 14, $281-287$.

150. Sattler FR, Qian D, Louie S, et al. (2001) Elevated blood pressure in subjects with lipodystrophy. AIDS $\mathbf{1 5}$, 2001-2010.

151. Thiébaut R, El-Sadr WM, Friis-Møller N, et al. (2005) Data collection of adverse events of anti-HIV Drugs Study Group. Predictors of hypertension and changes of blood pressure in HIV-infected patients. Antivir Ther 10, $811-823$.

152. Franklin SS (2008) Beyond blood pressure: arterial stiffness as a new biomarker of cardiovascular disease. J Am Soc Hypertens 2, 140-151.

153. van Vonderen MGA, Smulders YM, Stehouwer CDA, et al. (2009) Carotid intima-media thickness and arterial stiffness in HIV-infected patients: the role of HIV, antiretroviral therapy, and lipodystrophy. J Acquir Immune Defic Syndr 50, 153-161.

154. Vigano A, Bedogni G, Cerini C, et al. (2010) Both HIV-infection and long-term antiretroviral therapy are associated with increased common carotid intima-media thickness in HIV-infected adolescents and young adults. Curr HIV Res 8, 411-417.

155. Seaberg EC, Benning L, Sharrett AR, et al. (2010) Association between human immunodeficiency virus infection and stiffness of the common carotid artery. Stroke $\mathbf{4 1}$, $2163-2170$

156. Shankar SS \& Dubé MP (2004) Clinical aspects of endothelial dysfunction associated with human immunodeficiency virus infection and antiretroviral agents. Cardiovasc Toxicol 4, 261-269.

157. Stein JH, Klein MA, Bellehumeur JL, et al. (2001) Use of human immunodeficiency virus-1 protease inhibitors is associated with atherogenic lipoprotein changes and endothelial dysfunction. Circulation 104, 257-262.

158. Dubé MP, Shen C, Mather KJ, et al. (2010) Relationship of body composition, metabolic status, antiretroviral use, and HIV disease factors to endothelial dysfunction in HIV-infected subjects. AIDS Res Hum Retroviruses 26, $847-854$.

159. Torriani FJ, Komarow L, Parker RA, et al. (2008) Endothelial function in human immunodeficiency virus-infected antiretroviral-naive subjects before and after starting potent antiretroviral therapy: The ACTG (AIDS Clinical Trials Group) Study 5152s. J Am Coll Cardiol 52, 569-576.

160. Lefèvre C, Auclair M, Boccara F, et al. (2010) Premature senescence of vascular cells is induced by HIV protease inhibitors. Arterioscler Thromb Vasc Biol 30, 2611-2620.

161. Coll B, Parra S, Alonso-Villaverde C, et al. (2006) HIV-infected patients with lipodystrophy have higher rates of carotid atherosclerosis: the role of monocyte chemoattractant protein-1. Cytokine 34, 51-55.

162. Calza L, Manfredi R, Pocaterra D, et al. (2008) Risk of premature atherosclerosis and ischemic heart disease associated with HIV infection and antiretroviral therapy. J Infect 57, 16-32.

163. Kaplan RC, Kingsley LA, Gange SJ, et al. (2008) Low CD4 ${ }^{+}$ T-cell count as a major atherosclerosis risk factor in HIVinfected women and men. AIDS 22, 1615-1624.

164. Henry K, Melroe H, Huebsch J, et al. (1998) Severe premature coronary artery disease with protease inhibitors. Lancet 351, 1328.
165. Vittecoq D, Escaut L \& Monsuez JJ (1998) Vascular complications associated with use of HIV protease inhibitors. Lancet 351, 1959.

166. Bozzette SA, Ake CF, Tam HK, et al. (2003) Cardiovascular and cerebrovascular events in patients treated for human immunodeficiency virus infection. $N$ Engl J Med 348, $702-710$.

167. Sabin CA, Worm SW, Weber R, et al. (2008) Use of nucleoside reverse transcriptase inhibitors and risk of myocardial infarction in HIV-infected patients enrolled in the D:A:D study: a multi-cohort collaboration. Lancet 371, 1417-1426.

168. Barbaro G, Di Lorenzo G, Cirelli A, et al. (2003) An openlabel, prospective, observational study of the incidence of coronary artery disease in patients with HIV infection receiving highly active antiretrovial therapy. Clin Ther $\mathbf{2 5}$, 2405-2418.

169. Mallewa JE, Higgins SP, Garbett S, et al. (2009) Cardiovascular disease risk management in HIV patients, experiences from Greater Manchester. Int J STD AIDS 20, 425-426.

170. Alvarez C, Salazar R, Galindez J, et al. (2010) Metabolic syndrome in HIV-infected patients receiving antiretroviral therapy in Latin America. Braz J Infect Dis 14, 256-263.

171. Schafer JJ, Short WR \& Squires KE (2010) Association between abacavir exposure and increased risk for cardiovascular disease in patients with human immunodeficiency virus. Pharmacotherapy 30, 1072-1083.

172. Martin A, Amin J, Cooper D, et al. (2010) Abacavir does not affect circulating levels of inflammatory or coagulopathic biomarkers in suppressed HIV: a randomized clinical trial. AIDS 24, 2657-2663.

173. Schillaci G, Pucci G \& De Socio GVL (2009) HIV infection and antiretroviral treatment: a two-hit model for arterial stiffness. Am J Hypertens 22, 817-818.

174. Phillips AN, Carr A, Neuhaus J, et al. (2008) Interruption of antiretroviral therapy and risk of cardiovascular disease in persons with HIV-1 infection: exploratory analyses from the SMART trial. Antivir Ther 13, 177-187.

175. Calmy A, Gayet-Ageron A, Montecucco F, et al. (2009) HIV increases markers of cardiovascular risk: results from a randomized, treatment interruption trial. AIDS 23, 929-939.

176. Anderson KM, Odell PM, Wilson PWF, et al. (1991) Cardiovascular disease risk profiles. Am Heart J 121, 293-298.

177. Friis-Møller N \& Worm SW (2007) Editorial commentary: can the risk of cardiovascular disease in HIV-infected patients be estimated from conventional risk prediction tools? Clin Infect Dis 45, 1082-1084.

178. May M, Sterne JA, Shipley M, et al. (2007) A coronary heart disease risk model for predicting the effect of potent antiretroviral therapy in HIV-1 infected men. Int J Epidemiol 36, 1309-1318.

179. Hammond E, McKinnon E \& Nolan D (2010) Human immunodeficiency virus treatment-induced adipose tissue pathology and lipoatrophy: prevalence and metabolic consequences. Clin Infect Dis 51, 591-599.

180. Johnson JA, Albu JB, Engelson ES, et al. (2004) Increased systemic and adipose tissue cytokines in patients with HIV-associated lipodystrophy. Am J Physiol Endocrinol Metab 286, E261-E271.

181. Lagathu C, Eustace B, Prot M, et al. (2007) Some HIV antiretrovirals increase oxidative stress and alter chemokine, cytokine or adiponectin production in human adipocytes and macrophages. Antivir Ther 12, 489-500.

182. Kim RJ, Wilson CG, Wabitsch M, et al. (2006) HIV protease inhibitor-specific alterations in human adipocyte differentiation and metabolism. Obesity 14, 994-1002.

183. Jan V, Cervera P, Maachi M, et al. (2004) Altered fat differentiation and adipocytokine expression are inter-related 
and linked to morphological changes and insulin resistance in HIV-1-infected lipodystrophic patients. Antivir Ther 9, 555-564.

184. Sievers M, Walker UA, Sevastianova K, et al. (2009) Gene expression and immunohistochemistry in adipose tissue of HIV type 1-infected patients with nucleoside analogue reverse transcriptase inhibitor-associated lipodystrophy. J Infect Dis 200, 252-262.

185. Bastard J-P, Maachi M, van Nhieu JT, et al. (2002) Adipose tissue IL-6 content correlates with resistance to insulin activation of glucose uptake both in vivo and in vitro. J Clin Endocrinol Metab 87, 2084-2089.

186. Domingo P, Vidal F, Domingo JC, et al. (2005) Tumour necrosis factor $\alpha$ in fat redistribution syndromes associated with combination antiretroviral therapy in HIV-1-infected patients: potential role in subcutaneous adipocyte apoptosis. Eur J Clin Invest 35, 771-780.

187. Kovsan J, Ben-Romano R, Souza SC, et al. (2007) Regulation of adipocyte lipolysis by degradation of the perilipin protein. J Biol Chem 282, 21704-21711.

188. Mallewa JE, Wilkins E, Vilar J, et al. (2008) HIVassociated lipodystrophy: a review of underlying mechanisms and therapeutic options. J Antimicrob Chemother 62 , 648-660.

189. Rudich A, Ben-Romano R, Etzion S, et al. (2005) Cellular mechanisms of insulin resistance, lipodystrophy and atherosclerosis induced by HIV protease inhibitors. Acta Physiol Scand 183, 75-88.

190. Zhang HH, Halbleib M, Ahmad F, et al. (2002) Tumor necrosis factor- $\alpha$ stimulates lipolysis in differentiated human adipocytes through activation of extracellular signal-related kinase and elevation of intracellular cAMP. Diabetes 51, 2929-2935.

191. Rydén M, Arvidsson E, Blomqvist L, et al. (2004) Targets for TNF- $\alpha$-induced lipolysis in human adipocytes. Biochem Biophys Res Commun 318, 168-175.

192. Adler-Wailes D, Guiney EL, Koo J, et al. (2008) Effects of ritonavir on adipocyte gene expression: evidence for a stress-related response. Obesity 16, 2379-2387.

193. Giralt M, Domingo P, Guallar JP, et al. (2006) HIV-1 infection alters gene expression in adipose tissue, which contributes to HIV-1/HAART-associated lipodystrophy. Antivir Ther 11, 729-740.

194. Bezante GP, Briatore L, Rollando D, et al. (2009) Hypoadiponectinemia in lipodystrophic HIV individuals: a metabolic marker of subclinical cardiac damage. Nutr Metab Cardiovasc Dis 19, 277-282.

195. Körner A, Wabitsch M, Seidel B, et al. (2005) Adiponectin expression in humans is dependent on differentiation of adipocytes and down-regulated by humoral serum components of high molecular weight. Biochem Biophys Res Commun 337, 540-550.

196. Pacenti M, Barzon L, Favaretto F, et al. (2006) Microarray analysis during adipogenesis identifies new genes altered by antiretroviral drugs. AIDS 20, 1691-1705.

197. Lindegaard B, Keller P, Bruunsgaard H, et al. (2004) Low plasma level of adiponectin is associated with stavudine treatment and lipodystrophy in HIV-infected patients. Clin Exp Immunol 135, 273-279.

198. Sevastianova K, Sutinen J, Kannisto K, et al. (2008) Adipose tissue inflammation and liver fat in patients with highly active antiretroviral therapy-associated lipodystrophy. Am J Physiol Endocrinol Metab 295, E85-E91.

199. Caron M, Auclair M, Lagathu C, et al. (2004) The HIV-1 nucleoside reverse transcriptase inhibitors stavudine and zidovudine alter adipocyte functions in vitro. AIDS 18, $2127-2136$.
200. Grigem S, Fischer-Posovszky P, Debatin KM, et al. (2005) The effect of the HIV protease inhibitor ritonavir on proliferation, differentiation, lipogenesis, gene expression and apoptosis of human preadipocytes and adipocytes. Horm Metab Res 37, 602-609.

201. Kim MJ, Leclercq PE, Lanoy E, et al. (2007) A 6-month interruption of antiretroviral therapy improves adipose tissue function in HIV-infected patients: the ANRS EP29 Lipostop Study. Antivir Ther 12, 1273-1283.

202. Villarroya F, Domingo P \& Giralt M (2010) Drug-induced lipotoxicity: lipodystrophy associated with HIV-1 infection and antiretroviral treatment. $B B A-M o l$ Cell Biol L 1801, 392-399.

203. Venhoff N, Setzer B, Melkaoui K, et al. (2007) Mitochondrial toxicity of tenofovir, emtricitabine and abacavir alone and in combination with additional nucleoside reverse transcriptase inhibitors. Antivir Ther 12, 1075-1085.

204. Birkus G, Hitchcock MJM \& Cihlar T (2002) Assessment of mitochondrial toxicity in human cells treated with tenofovir: comparison with other nucleoside reverse transcriptase inhibitors. Antimicrob Agents Chemother 46, 716-723.

205. Viengchareun S, Caron M, Auclair M, et al. (2007) Mitochondrial toxicity of indinavir, stavudine and zidovudine involves multiple cellular targets in white and brown adipocytes. Antivir Ther 12, 919-929.

206. Walker UA, Setzer B \& Venhoff N (2002) Increased longterm mitochondrial toxicity in combinations of nucleoside analogue reverse-transcriptase inhibitors. AIDS 16, $2165-2173$

207. Ribera E, Paradiñeiro JC, Curran A, et al. (2008) Improvements in subcutaneous fat, lipid profile, and parameters of mitochondrial toxicity in patients with peripheral lipoatrophy when stavudine is switched to tenofovir (LIPOTEST Study). HIV Clin Trials 9, 407-417.

208. Caron M, Auclairt M, Vissian A, et al. (2008) Contribution of mitochondrial dysfunction and oxidative stress to cellular premature senescence induced by antiretroviral thymidine analogues. Antivir Ther 13, 27-38.

209. Walker UA, Auclair M, Lebrecht D, et al. (2006) Uridine abrogates the adverse effects of antiretroviral pyrimidine analogues on adipose cell functions. Antivir Ther 11, 25-34.

210. Sension M, de Andrade Neto JL, Grinsztejn B, et al. (2009) Improvement in lipid profiles in antiretroviral-experienced HIV-positive patients with hyperlipidemia after a switch to unboosted atazanavir. J Acquir Immune Defic Syndr 51, 153-162.

211. Sivakumar T, Mechanic O, Fehmie D, et al. (2011) Growth hormone axis treatments for HIV-associated lipodystrophy: a systematic review of placebo-controlled trials. HIV Med 12, 453-462.

212. Tungsiripat M \& Aberg JA (2005) Dyslipidemia in HIV patients. Clev Clin J Med 72, 1113-1120.

213. Dubé MP, Stein JH, Aberg JA, et al. (2003) Guidelines for the evaluation and management of dyslipidemia in human immunodeficiency virus (HIV)-infected adults receiving antiretroviral therapy: recommendations of the HIV Medicine Association of the Infectious Disease Society of America and the Adult AIDS Clinical Trials Group. Clin Infect Dis 37, 613-627.

214. Fichtenbaum C, Gerber JG, Rosenkranz SL, et al. (2002) Pharmacokinetic interactions between protease inhibitors and statins in HIV seronegative volunteers: ACTG Study A5047. AIDS 16, 569-577.

215. Feldt T, Oette M, Kroidl A, et al. (2006) Evaluation of safety and efficacy of rosiglitazone in the treatment of HIVassociated lipodystrophy syndrome. Infection 34, 55-61. 
216. Raboud JM, Diong C, Carr A, et al. (2010) A meta-analysis of six placebo-controlled trials of thiazolidinedione therapy for HIV lipoatrophy. HIV Clin Trials 11, 39-50.

217. Hadigan C, Corcoran C, Basgoz N, et al. (2000) Metformin in the treatment of HIV lipodystrophy syndrome: a randomized controlled trial. JAMA 284, 472-477.

218. van Wijk JPH, Hoepelman AIM, de Koning EJP, et al. (2011) Differential effects of rosiglitazone and metformin on postprandial lipemia in patients with HIV-lipodystrophy. Arterioscler Thromb Vasc Biol 31, 228-233.

219. Jiménez-Nácher I, Alvarez E, Morello J, et al. (2011) Approaches for understanding and predicting drug interactions in human immunodeficiency virus-infected patients. Expert Opin Drug Metab Toxicol 7, 457-477.

220. Martínez E (2011) Disorders of fat partitioning in treated HIV-infection. Best Prac Res Clin Endocrinol Metab 25, 415-427.

221. van Vonderen MGA, Gras L, Wit F, et al. (2009) Baseline lipid levels rather than the presence of reported body shape changes determine the degree of improvement in lipid levels after switching to atazanavir. HIV Clin Trials 10, 168-180.

222. Psaty BM \& Furberg CD (2007) Rosiglitazone and cardiovascular risk. $N$ Engl J Med 356, 2522-2524.

223. Hultman CS, McPhail LE, Donaldson JH, et al. (2007) Surgical management of HIV-associated lipodystrophy: role of ultrasonic-assisted liposuction and suction-assisted lipectomy in the treatment of lipohypertrophy. Ann Plas Surg $\mathbf{5 8}, 255-263$.

224. Warren A \& Borud LJ (2008) Excisional lipectomy for HIVassociated cervicodorsal lipodystrophy. Aesthet Surg $J \mathbf{2 8}$, $147-152$.

225. Moreno S, Miralles C, Negredo E, et al. (2009) Disorders of body fat distribution in HIV-1-infected patients. AIDS Rev 11, 126-134.

226. Skeie L, Bugge H, Negaard A, et al. (2010) Large particle hyaluronic acid for the treatment of facial lipoatrophy in HIV-positive patients: 3-year follow-up study. HIV Med 11, 170-177.

227. Dollfus C, Blanche S, Trocme N, et al. (2009) Correction of facial lipoatrophy using autologous fat transplants in HIV-infected adolescents. HIV Med 10, 263-268.

228. Narciso P, Bucciardini R, Tozzi V, et al. (2009) Immediate versus delayed surgical intervention for reconstructive therapy of HIV-associated facial lipoatrophy: a randomized open-label study. AIDS Res Hum Retroviruses 25, 979-987.

229. Guaraldi G, Squillace N, De Fazio D, et al. (2009) Heterologous fat transplantation for the treatment of HIV-related facial lipoatrophy. Ann Intern Med 150, 61-63.

230. Terry L, Sprinz E, Stein R, et al. (2006) Exercise training in HIV-1-infected individuals with dyslipidemia and lipodystrophy. Med Sci Sports Exerc 38, 411-417.

231. Roubenoff R, Weiss L, McDermott A, et al. (1999) A pilot study of exercise training to reduce trunk fat in adults with HIV-associated fat redistribution. AIDS $\mathbf{1 3}$, $1373-1375$.

232. Jones SP, Doran DA, Leatt PB, et al. (2001) Short-term exercise training improves body composition and hyperlipidaemia in HIV-positive individuals with lipodystrophy. AIDS 15, 2049-2051.

233. Yarasheski KE \& Roubenoff R (2001) Exercise treatment for HIV-associated medical and anthropomorphic complications. Exerc Sport Sci Rev 29, 170-174.

234. Fillipas S, Cherry CL, Cicuttini F, et al. (2010) The effects of exercise training on metabolic and morphological outcomes for people living with HIV: a systematic review of randomised controlled trials. HIV Clin Trials 11, 270-282.
235. Florindo AA, Rosario Dias de Oliveira Latorre Mdo R, Jaime PC, et al. (2007) Leisure time physical activity prevents accumulation of central fat in HIV/AIDS subjects on highly active antiretroviral therapy. Int J STD AIDS 18, 692-696.

236. Yarasheski KE, Tebas P, Stanerson B, et al. (2001) Resistance exercise training reduces hypertriglyceridemia in HIV-infected men treated with antiviral therapy. J Appl Physiol 90, 133-138.

237. Lindegaard B, Hansen T, Hvid T, et al. (2008) The effect of strength and endurance training on insulin sensitivity and fat distribution in human immunodeficiency virus-infected patients with lipodystrophy. J Clin Endocrinol Metab 93 , 3860-3869.

238. Hadigan C (2003) Dietary habits and their association with metabolic abnormalities in human immunodeficiency virusrelated lipodystrophy. Clin Infect Dis 37, Suppl. 2, S101-S104.

239. Gavrila A, Tsiodras S, Doweiko J, et al. (2003) Exercise and vitamin $\mathrm{E}$ intake are independently associated with metabolic abnormalities in human immunodeficiency viruspositive subjects: a cross-sectional study. Clin Infect Dis 36, 1593-1601.

240. Batterham MJ, Garsia R \& Greenop PA (2000) Dietary intake, serum lipids, insulin resistance and body composition in the era of highly active antiretroviral therapy 'Diet FRS Study'. AIDS 14, 1839-1843.

241. Samaras K, Wand H, Law M, et al. (2009) Dietary intake in HIV-infected men with lipodystrophy: relationships with body composition, visceral fat, lipid, glucose and adipokine metabolism. Curr HIV Res 7, 454-461.

242. Barrios A, Blanco F, Garcia-Benayas T, et al. (2002) Effect of dietary intervention on highly active antiretroviral therapyrelated dyslipemia. AIDS 16, 2079-2081.

243. Ng G, Chan U, Li P, et al. (2011) Can a Mediterranean diet reduce the effect of lipodystrophy syndrome in people living with HIV? A pilot randomised controlled trial. Sex Health 8, 43-51.

244. Roubenoff R, Schmitz H, Bairos L, et al. (2002) Reduction of abdominal obesity in lipodystrophy associated with human immunodeficiency virus infection by means of diet and exercise: case report and proof of principle. Clin Infect Dis 34, 390-393.

245. Vázquez C, Reyes R, Alcaraz F, et al. (2006) Eucaloric substitution of medium chain triglycerides for dietary long chain fatty acids improves body composition and lipid profile in a patient with human immunodeficiency virus lipodystrophy. Nutr Hosp 21, 552-555.

246. Famularo G, Moretti S, Marcellini S, et al. (1997) Acetylcarnitine deficiency in AIDS patients with neurotoxicity on treatment with antiretroviral nucleoside analogues. AIDS 11, 185-190.

247. Benedini S, Perseghin G, Terruzzi I, et al. (2009) Effect of L-acetylcarnitine on body composition in HIV-related lipodystrophy. Horm Metab Res 41, 840-845.

248. McComsey GA, O'Riordan M, Setzer B, et al. (2007) Uridine supplementation in HIV lipoatrophy: pilot trial on safety and effect on mitochondrial indices. Eur J Clin Nutr 62, 1031-1037.

249. Calmy A, Bloch M, Wand H, et al. (2010) No significant effect of uridine or pravastatin treatment for HIV lipoatrophy in men who have ceased thymidine analogue nucleoside reverse transcriptase inhibitor therapy: a randomized trial. HIV Med 11, 493-501.

250. Sutinen J, Walker UA, Sevastianova K, et al. (2007) Uridine supplementation for the treatment of antiretroviral therapy-associated lipoatrophy: a randomized, doubleblind, placebo-controlled trial. Antivir Ther 12, 97-105. 
251. Kamanna VS \& Kashyap ML (2008) Mechanism of action of niacin. Am J Cardiol 101, Suppl. 1, S20-S26.

252. Balasubramanyam A, Coraza I, Smith EO, et al. (2011) Combination of niacin and fenofibrate with lifestyle changes improves dyslipidemia and hypoadiponectinemia in HIV patients on antiretroviral therapy: results of "heart positive," a randomized, controlled trial. J Clin Endocrinol Metab 96, 2236-2247.

253. Kosmiski LA, Bessesen DH, Stotz SA, et al. (2007) Shortterm energy restriction reduces resting energy expenditure in patients with HIV lipodystrophy and hypermetabolism. Metabolism 56, 289-295.

254. Kosmiski LA, Kuritzkes DR, Sharp TA, et al. (2003) Total energy expenditure and carbohydrate oxidation are increased in the human immunodeficiency virus lipodystrophy syndrome. Metabolism 52, 620-625.

255. Kosmiski LA, Bessesen DH, Stotz SA, et al. (2007) Shortterm overfeeding increases resting energy expenditure in patients with HIV lipodystrophy. Am J Clin Nutr 86, 1009-1015.

256. Razzini E \& Baronzio GF (1993) Omega-3 fatty acids as coadjuvant treatment in AIDS. Med Hypotheses 41, $300-305$.

257. De Truchis P, Kirstetter M, Perier A, et al. (2007) Reduction in triglyceride level with $n-3$ polyunsaturated fatty acids in HIV-infected patients taking potent antiretroviral therapy: a randomized prospective study. J Acquir Immune Defic Syndr 44, 278-285.

258. Wohl DA, Tien HC, Busby M, et al. (2005) Randomized study of the safety and efficacy of fish oil (omega-3 fatty acid) supplementation with dietary and exercise counseling for the treatment of antiretroviral therapy-associated hypertriglyceridemia. Clin Infect Dis 41, 1498-1504.

259. Gerber JG, Kitch DW, Fichtenbaum CJ, et al. (2008) Fish oil and fenofibrate for the treatment of hypertriglyceridemia in HIV-infected subjects on antiretroviral therapy: results of ACTG A5186. J Acquir Immune Defic Syndr 47, 459-466.

260. Manfredi R, Calza L \& Chiodo F (2004) Polyunsaturated ethyl esters of $n-3$ fatty acids in HIV-infected patients with moderate hypertriglyceridemia: comparison with dietary and lifestyle changes, and fibrate therapy. $J$ Acquir Immune Defic Syndr 36, 878-880.

261. Baril J, Kovacs CM, Trottier S, et al. (2007) Effectiveness and tolerability of oral administration of low-dose salmon oil to
HIV patients with HAART-associated dyslipidemia. HIV Clin Trials 8, 400-411.

262. Ranieri R (2007) Effect of omega-3 fatty acids on the lipid structure of HIV-positive patients on antiretroviral therapy: personal observation of 20 subjects (article in Italian). Infez Med 15, 237-241.

263. Hellerstein MK, Wu K, McGrath M, et al. (1996) Effects of dietary $n-3$ fatty acid supplementation in men with weight loss associated with the acquired immune deficiency syndrome: relation to indices of cytokine production. $J$ Acquir Immune Defic Syndr Hum Retrovirol 11, 258-270.

264. Carter VM, Woolley I, Jolley D, et al. (2006) A randomised controlled trial of omega-3 fatty acid supplementation for the treatment of hypertriglyceridemia in HIV-infected males on highly active antiretroviral therapy. Sex Health 3, 287-290.

265. Virgili N, Farriol M, Castellanos JM, et al. (1997) Evaluation of immune markers in asymptomatic AIDS patients receiving fish oil supplementation. Clin Nutr 16, 257-261.

266. Normén L, Yip B, Montaner J, et al. (2007) Use of metabolic drugs and fish oil in HIV-positive patients with metabolic complications and associations with dyslipidaemia and treatment targets. HIV Med 8, 346-356.

267. Calder PC (2002) Dietary modification of inflammation with lipids. Proc Nutr Soc 61, 345-358.

268. Weldon SM, Mullen AC, Loscher CE, et al. (2007) Docosahexaenoic acid induces an anti-inflammatory profile in lipopolysaccharide-stimulated human THP-1 macrophages more effectively than eicosapentaenoic acid. J Nutr Biochem 18, 250-258.

269. Mullen A, Loscher CE \& Roche HM (2010) Anti-inflammatory effects of EPA and DHA are dependent upon time and dose-response elements associated with LPS stimulation in THP-1-derived macrophages. J Nutr Biochem 21, 444-450.

270. Pichard C, Sudre P, Karsegard V, et al. (1998) A randomized double-blind controlled study of 6 months of oral nutritional supplementation with arginine and $\Omega-3$ fatty acids in HIV-infected patients. Swiss HIV Cohort Study. AIDS 12, 53-63.

271. Bell S, Chavali S, Bistrian BR, et al. (1996) Dietary fish oil and cytokine and eicosanoid production during human immunodeficiency virus infection. JPEN J Parenter Enteral Nutr 20, 43-49. 